HID 41 (2014)

\title{
LA COMPOSICIÓN DE LOS ALMOJARIFAZGOS SEÑORIALES DEL REINO DE SEVILLA, SIGLOS XIII-XV ${ }^{1}$
}

\author{
THE COMPOSITION OF THE MANORIAL ALMOJARIFAZGOS OF THE \\ KINGDOM OF SEVILLE, $13^{\mathrm{TH}}-15^{\mathrm{TH}}$ CENTURIES
}

\author{
José Damián GonzÁlez Arce \\ Universidad de Murcia \\ josedam@um.es
}

RESUMEN: La conquista de los territorios musulmanes proporcionó a los reyes castellanos las rentas antes percibidas por los reyes de taifas. Muchas fueron agrupadas en el tesoro real de cada localidad, llamado almojarifazgo. Como los monarcas no pudieron administrar, por falta de medios, el inmenso espacio incorporado a la Corona, entregaron extensos dominios a grandes señores. Y, junto a ellos, sus respectivos almojarifazgos. La nobleza terrateniente nutrió sus haciendas a partir de tales derechos, que constituyeron una de las bases de su poder político y militar y pudo recaudar gracias a las concesiones reales, de manera que los conservó sin cambios para garantizar la legitimidad de su percepción. Esta fidelidad al pasado y el esfuerzo por no perder ingresos hicieron que muchas de estas exacciones, desaparecidas o transformadas en territorios de realengo, se mantuviesen inalteradas en los señoriales, y así podamos acercarnos a cómo fueron en origen, e incluso en tiempos musulmanes.

PALABRAS CLAVE: almojarifazgo, fiscalidad musulmana, renta señorial, mercado, comercio.

ABSTRACT: The conquest of Muslim emirates provided the Castilian kings before income received by the party kings. Many of them were grouped in the royal treasure of each locality, called almojarifazgo. As monarchs could not manage, for lack of means, the immense joined the Crown dominions extensive territory gave great lords. The monarchs delivered the territories who not could manage to lords, including their almojarifazgos. The landed gentry used this incomes as base on their political and military power. This incomes could be enjoyed by royal privi-

1. Abreviaturas utilizadas: $\mathrm{AC}=$ Acta Capitular; $\mathrm{AGS}=$ Archivo General de Simancas; AHN $=$ Archivo Histórico Nacional; AMJF = Archivo Municipal de Jerez de la Frontera; CC = Cámara de Castilla; LC = Libro de Copia; PR = Patronato Real; $\mathrm{SN}=$ Sección Nobleza. Este artículo ha sido realizado en el marco del proyecto HAR2011-26218, titulado "Fiscalidad y sociedad en la Corona de Castilla al sur del Tajo", integrado en la red Arca Comunis. Agradezco a los evaluadores su trabajo y las sugerencias recibidas, que han contribuido a la mejora de esta versión final. 
leges, and kept unchanged to ensure its legitimacy. This fidelity to the past allows us to study how these rents were originally.

KEYWORDS: almojarifazgo, Muslim taxation, rent manor, market, trade.

\section{INTRODUCCIÓN}

Este artículo tiene como cometido establecer una comparación entre las rentas comprendidas en los almojarifazgos señoriales de la baja Andalucía, con dos objetivos: conocer su origen y composición y señalar las similitudes existentes entre ellas. Con ello, se habrá dado un paso más para desvelar la extremadamente compleja, y a veces casi inextricable, naturaleza del propio almojarifazgo. Se trató tanto de un conjunto de exacciones de origen musulmán, luego cobradas tras la conquista de cada población por los nuevos poderes políticos, monarquía castellana, concejos y señores; así como de un impuesto exigido sobre el tráfico comercial foráneo a la circunscripción fiscal donde era demandado, incluido el exterior al reino de Castilla. Sobre esta amalgama fiscal queda mucho por saber, porque cada uno de estos regímenes de tesorería local conjunta fue diferente al resto y estuvo compuesto por una gran cantidad de imposiciones variables a lo largo del tiempo, en su número y en su tipo ${ }^{2}$.

2. Los primeros estudios sobre el almojarifazgo se los debemos a M.A. Ladero Quesada. En el que podemos considerar como pionero ("Almojarifazgo sevillano y comercio exterior de Andalucía en el siglo XV". Anuario de Historia Económica y Social, 2, 1969), realizó un exhaustivo análisis sobre el origen y evolución de esta renta en Sevilla, base de posteriores trabajos suyos como, La hacienda real de Castilla en el siglo XV. La Laguna, 1973, donde, en las páginas 95-150, aborda las aduanas de Castilla, y con ellas los almojarifazgos del sur, tanto los andaluces (sevillano y cordobés, y en parte el jerezano, el jienense y otros), como el murciano y el toledano. Las conclusiones a las que llegó en estas obras iniciales fueron luego recogidas y ampliadas en otras posteriores: Fiscalidad y poder real en Castilla (1252-1369). Madrid, 1993, pp. 140-155, donde estableció una clasificación de la tipología de las exacciones comprendidas en este régimen conjunto de derechos. Algo que vuelve a aparecer en su libro más reciente, $L a$ Hacienda Real de Castilla, 1369-1504. Madrid, 2009. El autor que de manera más sistemática está abordado el análisis de los almojarifazgos castellanos es J.D. González Arce. Labor que comenzara con "El almojarifazgo de Sevilla, una renta feudal". Actas del VI Coloquio Internacional de Historia Medieval de Andalucía. Las ciudades Andaluzas (siglos XIII-XVI). Málaga, 1991, donde se planteó la naturaleza jurídica de dicho conjunto de tributos. Para más tarde pasar al estudio de los diferentes almojarifazgos locales, que comenzó por Murcia ("La política fiscal de Alfonso X en el reino de Murcia: portazgo y diezmos". Studia Historica, Historia Medieval (en adelante, SH), 10, 1992. "Almojarifazgo y economía urbana en el reino de Murcia, siglo XIII”. Hispania, 53, 1993. La fiscalidad del señorío de Villena en la baja Edad Media. Albacete, 2002. "De conjunto de rentas a impuesto aduanero. La transformación del almojarifazgo durante el siglo XIV en el reino de Murcia". Anuario de Estudios Medievales (en adelante, AEM), 42/2, 2012). Seguida de Sevilla ("Documentos sobre el almojarifazgo de Sevilla". Historia. Instituciones. Documentos (en adelante, HID), 20, 1993. "Las rentas del almojarifazgo de Sevilla", SH, 15, 1997. "Los beneficiarios de la fiscalidad medieval. El caso del diezmo del aceite del almojarifazgo de Sevilla en el siglo XV". Medievalismo, 22, 2012). Y, Toledo ("Las rentas del almojarifazgo de Toledo". Anales Toledanos, 61, 2005. "Del diezmo islámico al diezmo real. La renta agraria en Toledo (ss. XI-XV)". Historia Agraria, 45, 2008). Del mismo modo, han tratado aspectos relacionados con el almojarifazgo otros autores, entre los que cabe citar a R. Peinado Santaella. "Fiscalidad señorial y tráfico comercial en Andalucía a finales de la Edad Media: Notas para su estudio". Hacienda y comercio. Actas del II coloquio 
Han sido elegidas para este análisis las haciendas nobiliarias también por dos motivos. Primero, porque los tributos en ellas contenidos, en muchas ocasiones, son los que se mantuvieron más parecidos a los originales y menos cambiaron con el tiempo; debido a que los señores basaron, en buena medida, su legitimidad para el cobro de estas punciones en la fidelidad con la que observaron los privilegios de donación que les otorgó la monarquía sobre sus tierras y los derechos que comprendían. De manera que los arbitrios de los almojarifazgos nobiliarios probablemente fueron los más próximos a las gabelas inicialmente cobradas en los emiratos y taifas musulmanas de las que procedían. En segundo lugar, por ese motivo, tal circunstancia tendría que haber contribuido a que los diferentes almojarifazgos señoriales de una determinada zona geográfica fuesen similares entre sí. Esto es lo que pretendo comprobar al estudiar los existentes en los estados nobiliarios del antiguo reino y arzobispado de Sevilla, localizados al sur de las actuales provincias de Sevilla y Huelva, y en la de Cádiz, muy cercanos entre sí; y que, de este modo, habrían tenido orígenes semejantes y habrían sufrido influencias mutuas.

Sin embargo, no hemos de olvidar que lo que se diga sobre las haciendas señoriales está sujeto a posteriores revisiones, debido a la gran cantidad de documentación que existe al respecto, en su mayor parte todavía desconocida, tanto por su propia abundancia como por la difícil y peculiar consulta de muchos de los archivos donde se halla conservada.

\section{CONQUISTA Y ORGANIZACIÓN JURÍDICA DEL TERRITORIO E IMPLICACIONES} FISCALES

Buena parte de las localidades conquistadas al sur de Sevilla fueron privilegiadas con la concesión del fuero de la capital hispalense, que ésta recibiera previamente de Toledo. Arcos de la Frontera lo obtuvo en 1256, y de nuevo en 1264; a Niebla, el Fuero Real y los privilegios de Sevilla le fueron dados en 1263, desde donde se trasvasaron al año siguiente a las ahora independientes Huelva y Gibraleón. En todas ellas, el Fuero Real habría dejado de tener vigencia hacia finales del reinado de Alfonso X, para acabar por imponerse el sevillano ${ }^{4}$. Derecho local hispalense que Arcos, otra vez, y Medina Sidonia recibieron el 27 de enero de 1268. A los caballeros de linaje de estas dos poblaciones les concedió dicho rey

de historia medieval andaluza. Sevilla, 1982. Para cuestiones metodológicas, véase A. Galán Sánchez. "Hacienda y fiscalidad en el reino de Granada: algunas razones para su estudio". Crónica Nova, 31, 2005.

3. Previamente, unos meses antes Alfonso X había entregado a la Orden de Calatrava dos aldeas en el término de esta plaza, con todas sus pertenencias, "assí cuemo las ouieron en tiempo de moros"; al igual que un molino sito en una de ellas, el cual pertenecía al almacén real, esto es, probablemente al almojarifazgo real local. En 1258, donó la aldea de Bornos a Per del Castel, igualmente con todos sus derechos, salvo 1/3 de ellos que pertenecían al alguacil de Jerez de la Frontera, gracias al pleito (pacto de pleitesía o de sometimiento) suscrito por la ciudad del Guadalete, todavía bajo protectorado (M. González Jiménez. Diplomatario andaluz de Alfonso X. Sevilla, 1991, pp. 177, 200-202, 228).

4. Ibid., pp. 292, 295-296, 326, 356; M.A. Ladero Quesada. Niebla, de reino a condado. Noticias sobre el Algarbe andaluz en la baja Edad Media. Madrid, 1992, pp. 19-22. 
las franquezas de los caballeros toledanos, mientras que a los restantes y al pueblo les otorgó los privilegios sevillanos ${ }^{5}$. En 1271, le dio a Morón de la Frontera el fuero de Sevilla ${ }^{6}$.

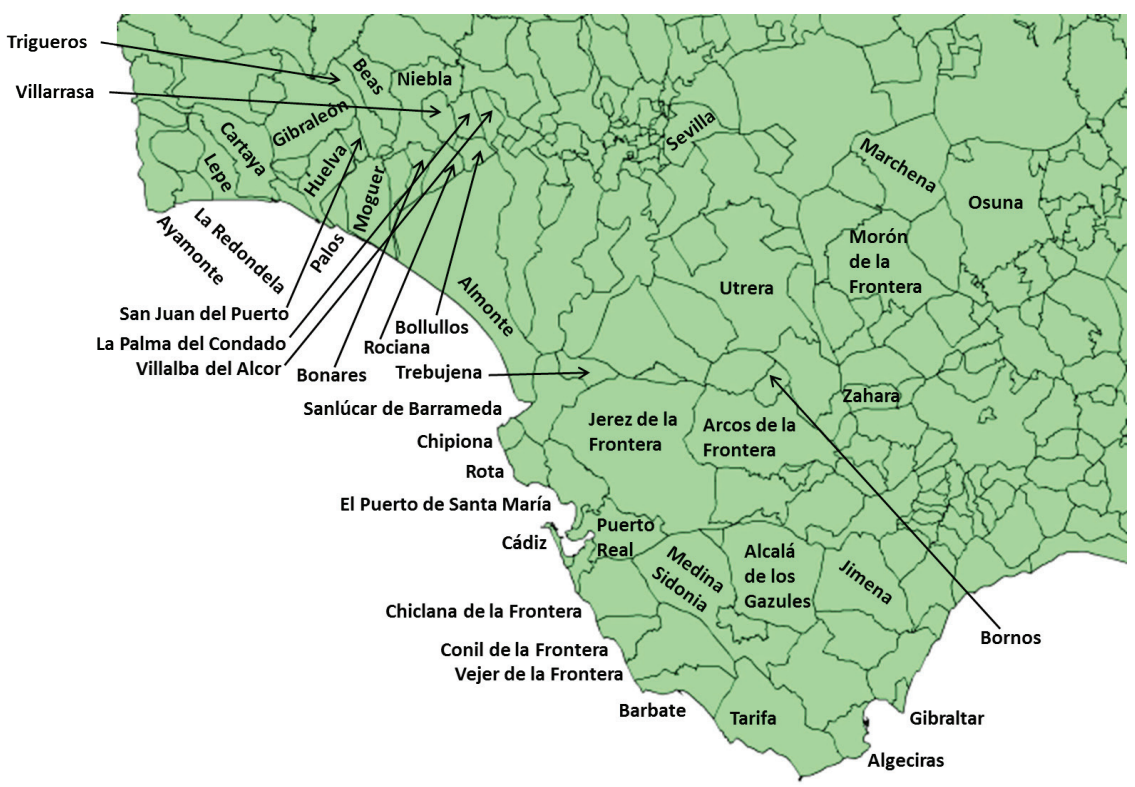

Mapa 1: Ubicación de los señoríos y localidades de la baja Andalucía citados en el presente trabajo

En este sentido, como es bien conocido, uno de los impuestos universalmente satisfecho por los musulmanes fue el diezmo islámico o zakat, que gravaba aproximadamente con el 10\% sus cosechas y ganados. Una vez conquistados los territorios al sur del Sistema Central, en los lugares con fuero toledano, los mudéjares que allí permanecieron continuaron abonando dicha exacción, ahora no a los emires sino al rey castellano, dentro del almojarifazgo local de cada lugar. Algo que ocurrió igualmente con los cristianos repobladores, hasta que fueron eximidos del

5. M.A. Ladero Quesada y M. González Jiménez. "La población de la frontera de Gibraltar y el repartimiento de Vejer (siglos XIII y XIV)". HID, 4, 1977, p. 225; M. González Jiménez. Diplomatario, pp. 368-372, 390-391; M.A. Ladero Quesada. Los señores de Andalucía. Investigaciones sobre nobles y señorios en los siglos XIII a XV. Cádiz, 1998, pp. 252-253. En 1496 el concejo de Medina Sidonia envió una carta al de Jerez para hacer guardar sus exenciones. Éste último respondió haber recibido años antes misivas reales en las que los Reyes Católicos ordenaban a los almojarifes jerezanos observar las franquezas de dicha ciudad ducal, a lo que éstos, con el respaldo del corregidor, respondieron que no debían hacerlo porque los privilegios que la avalaban no habían sido registrados por los contadores mayores. Por ello, el representante medinense mostró ese año 1496 otra vez documentos de los soberanos y sus contadores ante el nuevo corregidor xericense, al que pidió su cumplimiento (AMJF, AC 1496, f. 221v).

6. M. González Jiménez. Diplomatario, pp. 409-410; M. García Fernández. "Morón de la Frontera y Enrique II: los privilegios reales de 1378”. Archivo hispalense (en adelante, AH), 74, 227, 1991, pp. 21-22. 
gravamen o se les conmutó por el diezmo eclesiástico, una vez institucionalizado. De manera que para ellos, el antiguo diezmo islámico se convirtió en el diezmo real y hubieron de satisfacerlo durante un cierto lapso de tiempo tras la ocupación de sus tierras, de más de dos siglos en Toledo y de solo algunos años en Andalucía y Murcia. Posteriormente, este último desapareció o se transformó en el diezmo eclesiástico. No obstante, aunque en ciertos casos los campesinos cristianos debieron satisfacer ambos tributos simultáneamente, en otros el diezmo real se siguió cobrando únicamente sobre algunos productos de mayor valor, como el aceite del Aljarafe de Sevilla o el de Jerez de la Frontera, lo que bloqueó el pago de diezmo eclesiástico. Entre las rentas ducales de la Casa de Medina Sidonia se encontraba, a comienzos del siglo XVI, el diezmo del aceite de su villa de Trebujena, que bien pudo provenir, como los antedichos, del primitivo diezmo islámico; como los de Huelva y Ayamonte, también en manos señoriales?

Esta misma habría sido la situación vivida en las citadas localidades de Arcos y Medina pues, junto con sus privilegios de origen toledano-sevillano, el monarca franqueó a sus moradores del diezmo que debían pagarle los peones de Sevilla (antes de su propia exención), en función de lo dispuesto en el fuero de Toledo. Dicho diezmo real de origen islámico no solo afectaba a las cosechas y ganados, sino también a otros productos relacionados con la tierra, como los confeccionados con barro -caso de ladrillos y tejas-, que lo abonaban, por ejemplo, al almojarifazgo de Sevilla. En los lugares de señorío este diezmo de las labores del barro era propiedad de sus titulares, tal y como se recoge, por ejemplo, en la regulación sobre la cal, teja y ladrillo emitida en Palos en la década de 1480. Del mismo modo, en Huelva y el condado de Niebla, pertenecientes al duque de Medina Sidonia, las ordenanzas que éste otorgara en 1504 establecían que todo el diezmo de ese tipo percibido en sus estados se emplease en la reparación de sus fortificaciones; de manera que la cal, tejas y ladrillos cobrados en especie por el mayordomo señorial de las obras a pie de horno se destinarían al castillo local, en caso de que lo hubiese, o al más cercano, si no lo había allí mismo. En cuanto a Niebla, su señor solo recibía para el mantenimiento de sus fortalezas el diezmo de las labores del barro de algunas de sus aldeas o lugares comprendidos en su condado -Almonte, Bollullos, Rociana y Beas-, pues el de la propia villa era de su concejo y lo cobraba su almotacén. No obstante, este gravamen también se vio afectado por las decisiones del duque, que en 1493, tras dejarlo en suspenso, luego redujo su tipo al 5\% para la loza y al 2,5 para la loza vidriada. Como en los restantes señoríos de la Casa, también en Sanlúcar de Barrameda este diezmo de la cal teja y ladrillo se destinó a la reparación de su castillo ${ }^{8}$.

7. J.D. González Arce. "Del diezmo...”; J.D. González Arce. “Actividad económica y exacciones fiscales. El almojarifazgo de Jerez en los siglos XIII-XV”, Congreso Científico Jerez 1264-2014: 750 años, Jerez de la Frontera, 3-7 de febrero de 2014. J.D. González Arce. "Aproximación a la producción oleica del Aljarafe durante el siglo XV a partir de fuentes fiscales. El diezmo del aceite del almojarifazgo de Sevilla". Historia Agraria (en prensa); A. Moreno Ollero. Sanlúcar de Barrameda a fines de la Edad Media. Cádiz, 1983, p. 80; M.A. Ladero Quesada. Niebla, pp. 110, 130.

8. M.A. Ladero Quesada. Los señores, pp. 184, 207, 232, 238; M.A. Ladero Quesada. Niebla, pp. 72, 130; M.A. Ladero Quesada. "Sanlúcar de Barrameda, antepuerto de Sevilla, a finales del siglo 
Además de lo señalado para el diezmo real, la concesión del fuero y privilegios sevillanos a las localidades situadas al sur de dicha ciudad fue acompañada exenciones y franquicias en los derechos aduaneros incluidos en el almojarifazgo de cada lugar. Las más importantes de ellas fueron relativas al portazgo, considerado como la principal exacción castellana sobre el tráfico de mercancías hasta el siglo XIII, momento a partir del cual entró en decadencia al consistir en un gravamen fijo para cada producto -según su procedencia, peso, medida o volumen-, tal y como se contenía los extensos aranceles, en ocasiones comprendidos en los textos forales, como los de la familia de Cuenca. El mayor inconveniente de este impuesto, aparte de los complejos padrones en los que venía reglamentado, diferentes para cada localidad, era que su carácter de renta fija hacía que perdiese valor con el paso del tiempo, por efecto de la inflación de precios y de la depreciación de la moneda de cuenta en la que solía venir expresado el canon. Por ello, progresivamente fue reducido mediante numerosas y casi universales exenciones $\mathrm{y}$, en muchos de los casos en los que no desapareció, fue cedido a los concejos y señores territoriales. En su sustitución, la hacienda real implantó el diezmo aduanero en los puertos marítimos y en las fronteras exteriores al norte del Sistema Central y con Aragón. Mientras que en el sur se configuró el almojarifazgo aduanero?.

En un primer momento, dentro del almojarifazgo como conjunto de rentas se incluyeron los derechos a pagar en las aduanas de cada localidad exigidos en tiempos musulmanes. Éstos eran ad valorem -fijados en torno al $10 \%-$, y por lo tanto mucho más eficaces que el portazgo, al no precisar de la elaboración de complejos padrones para su recaudación ni devaluarse como consecuencia de la inflación. Solían ser designados por la tasa a pagar, de modo que eran en un principio conocidos como diezmo, quincena, veintena... Sin embargo, cuando estas tarifas iniciales fueron modificadas por los monarcas castellanos, generalmente a la baja para potenciar la repoblación de los territorios, como ocurrió en Murcia, esta primera denominación perdió su sentido y hubo que buscar un nuevo apelativo genérico que sirviese para llamar al gravamen independientemente del arancel exigido. Surgió así el término almojarifazgo referido en concreto al canon aduanero, tributo que, como los restantes pertenecientes al tesoro real de cada localidad, se integró en el almojarifazgo del lugar, entendido como conjunto de rentas. Un mismo nombre para dos conceptos diferentes, aunque relacionados, lo que ha llevado a cierta confusión a quienes se han acercado a la fiscalidad de estas poblaciones. Esta

\footnotetext{
XV". Mundos medievales: espacios, sociedades y poder: homenaje al profesor José Ángel García de Cortázar y Ruiz de Aguirre, Santander, 2012, p. 1.503; I. Galán Parra. "Las ordenanzas de 1504 para Huelva y el Condado de Niebla". Huelva en su Historia (en adelante, HH), 3, 1990, p. 112. En Marchena, esta renta incluía teja y ladrillo, cal y yeso, madera, cenizas de hornos de pan, etc. (E. Solano Ruiz. "La hacienda de las casas de Medina Sidonia y Arcos en la Andalucía del siglo XV". $A H, 55$, 168, 1972, pp. 96-97).

9. Sobre el portazgo castellano, C. González Mínguez. El portazgo en la Edad Media. Aproximación a su estudio en la Corona de Castilla. Bilbao, 1989. P.A. Porras Arboledas. "Las tasas sobre la circulación y venta de mercancías en León y Castilla durante la Edad Media". En la España Medieval (en adelante, $E E M), 5,1986$. Del mismo autor, "Los portazgos en León y Castilla durante la Edad Media. Política real y circuitos comerciales". EEM, 15, 1992.
} 
sinécdoque -tomar a la parte por el todo-, se explica en la consideración de este impuesto aduanero como una de las rentas de mayor importancia de las incluidas en el almojarifazgo. Además, con el paso del tiempo, buena parte de las restantes exacciones, o bien fueron suprimidas por su escaso interés para el erario real, o bien resultaron cedidas a los concejos para conformar las haciendas municipales. De manera que, a partir del siglo $\mathrm{XV}$, casi todos los almojarifazgos reales locales quedaron reducidos al derecho arancelario, más alguna exacción residual aneja de las primitivamente comprendidas en el conjunto de rentas, a excepción del almojarifazgo sevillano, donde éstas siguieron teniendo una gran importancia relativa ${ }^{10}$.

Con las franquezas sevillanas, en 1263 Niebla obtuvo exención de portazgo en toda Castilla, excepto en Sevilla, Toledo y Murcia, para las mercancías llevadas para su abastecimiento; privilegio confirmado en 1267 y ampliado en la ratificación de Fernando IV, de 1299, a cualquier otro derecho de tránsito. Del portazgo también estuvieron libres sus antiguas villas de Huelva y Gibraleón, aforadas según la localidad matriz, a partir de 1265 y 1266; esta última vio en 1303 aumentada además su merced con la redención del almojarifazgo. Según unas ordenanzas otorgadas por los duques de Mediana Sidonia a finales del siglo XV, los vecinos de Palos de la Frontera también eran libres de pagar por lo que allí llevasen para su aprovisionamiento, así como por los productos de su labranza y crianza. Por otras de comienzos del siglo XVI, sabemos que la descarga de mercancías en el Río Tinto era franca, pero se deduce que solo las adquiridas por los lugareños para llevarlas a sus casas. Si las revendían, abonarían almojarifazgo, que era del 2,5\% si lo comprado era reexportado, aunque nada debía darse si se sacaba por el río. Las materias primas de fuera adquiridas por cordoneros, esparteros o herreros pagaban el 5\% de arancel, frente a la franqueza disfrutada por los artículos que elaboraban. Por su parte, los zapateros y toneleros no abonaban nada por ambos conceptos ${ }^{11}$.

El Puerto de Santa María fue, por su estratégica ubicación, la localidad elegida por Alfonso X para instalar una marina de guerra permanente, para lo que le otorgó generosos privilegios. En primer lugar, el fuero de Sevilla, en 1281, que incluía para los vecinos exención en toda Castilla de portazgo, diezmo (almojarifazgo aduanero) y otros derechos de paso. Además, los no vecinos quedaron franqueados de pagarlos de lo que comprasen o vendiesen en la localidad. Tampoco darían nada los moradores propietarios de galeras por las mercancías que importasen y exportasen por dicho surgidero, siempre que sus naves arribasen a él al menos una vez al año. Los vecinos que comprasen o vendiesen género en otras poblaciones solamente debían abonar la mitad de los derechos correspondientes. Los comerciantes cristianos que acudiesen a la localidad estaban, asimismo, franqueados de portazgo, mientras que a los musulmanes se les rebajó un tercio. De otro lado, los beneficios obtenidos por los moradores con el corso y la pesca fueron igualmente

10. Sobre estos aspectos, M.A. Ladero Quesada. “Almojarifazgo...”; J.D. González Arce. "Las rentas del almojarifazgo de Sevilla..." y "De conjunto...".

11. M.A. Ladero Quesada. Niebla, pp. 19-22, 27-28; M.A. Ladero Quesada. Los señores, pp. 99101, 207, 211; A. González Gómez. "Ordenanzas municipales de Palos de la Frontera (1484-1521)". HID, 3, 1976, pp. 276-277. 
liberados de cualquier gravamen, siempre que lo capturado fuese vendido en la villa; a la cual le fueron concedidas dos ferias cada año, cuyas compraventas quedaron eximidas de toda tributación. En 1283, los pobladores recibieron la misma y extraordinaria merced que Murcia, para no pagar cosa alguna de lo que comprasen o vendiesen en todo el reino, posteriormente ratificada por Fernando IV en 1309. Además, el citado año 1283 Alfonso X había dispuesto que los barcos que remontasen el Guadalete camino de Jerez debían descargar un tercio de sus mercaderías en El Puerto.

Cádiz y su feria obtuvieron ventajas semejantes por parte de Alfonso X, según privilegios confirmados por sus sucesores. Entre ellas la franqueza de portazgo y maltolta (multa por la exportación de cosas vedadas) en toda Castilla, en 1263; la exención de diezmo (almojarifazgo aduanero); y la reducción de los derechos a abonar en la localidad por parte de los mercaderes forasteros, que satisfarían 1/3 menos del gravamen establecido en Sevilla. En un pleito, emprendido hacia 1554 por la capital hispalense contra un vecino gaditano, se contiene que los lugareños estaban en posesión antigua de no pagar almojarifazgo de lo que introdujesen por tierra en la ciudad y que, asimismo, gozaban de una franqueza para no hacerlo tampoco por todo lo que se metiese y sacase por mar o tierra ${ }^{12}$. Para demostrarlo aportaron un privilegio de confirmación de los Reyes Católicos (1493), mediante el que ratificaban otros 4 dados por Juan II (1420) y una carta de Enrique III (1405) ${ }^{13}$. El tercero de los citados privilegios del año 1420 avalaba otro de Enrique III (1391), que a su vez validaba otro de Juan I (1379), que lo hacía con uno de Alfonso XI (1363), y éste, otro de Alfonso X (1263), mediante el cual eximía a los gaditanos de portazgo, maltolta y otros derechos de exportación de sus bienes en toda Casti$1 \mathrm{a}^{14}$. En cuanto al cuarto, ratifica una carta de Sancho IV (1284) que hacía lo propio con otras 2 de Alfonso X que, entre otras cuestiones, informan de las libertades de los gaditanos: que estaban exentos de portazgo y otros derechos de todo lo que introdujesen o sacasen de la localidad; de portazgo y diezmo en toda Castilla; que los mercaderes forasteros pagaban en dicha población 1/3 menos que en Sevilla; y, que gozaban de una feria de un mes franca de portazgo, maltolta y otros derechos. Del mismo modo, Alfonso XI revalidó otra carta de su padre Fernando IV (1310) mediante la que, a petición del concejo de Cádiz, corroboró la exención de sus vecinos, dada por Alfonso X y Sancho IV, de diezmo, portazgo y otros derechos. El citado proceso fue ganado por los gaditanos, que hicieron valer sus franquezas.

12. AGS, PR, LC, 5, ff. 359-421. M. González Jiménez. Diplomatario, pp. 293-294, 570-572.

13. El primero de los del rey Juan era a su vez de corroboración de otro de Fernando IV (1310) dado a El Puerto de Santa María, con el que le comunicaba que Cádiz gozaba de privilegios de Sancho IV y Alfonso X mediante los que podía importar cereal libremente, sin pagar aranceles. Mientras que el segundo reafirmaba 3 cartas de Alfonso XI (1325), una de ellas remitida a los almojarifes de la aduana de Sevilla, en la que les recordaba cómo Fernando III había dado al concejo de Cádiz 3.944 mrs. a percibir de dicha aduana. En cuanto a la carta de Enrique III de 1391, hace mención a la prohibición de llevar vino a Cádiz.

14. Implícitamente fue también ratificado por Sancho IV (1284 y 1294), que confirmó todos los dados por su padre Alfonso X a Cádiz, así como por Fernando IV (1303). 
Por su parte, las localidades fronterizas con Granada también alcanzaron el mayor grado de privilegio, en atención a su delicada situación repobladora y al peligro permanente en el que se mantuvieron a lo largo de los siglos. Los vecinos y moradores de Medina Sidonia obtuvieron de Alfonso X en 1282 franqueza de portazgo de todo lo que introdujesen y exportasen del lugar, merced ampliada por su hijo Sancho IV en 1288 con la exención de diezmo (almojarifazgo). Rey que fue más generoso con la vecina Tarifa, a la que exoneró en 1295 no solo de portazgo y diezmo, sino también de veintena, cuarentena y alcabalas, esto es, las alcabalas viejas que veremos más abajo; además, los mercaderes no debían dar nada por las viandas y armas llevadas al puerto de la villa, ni los bajeles ancoraje, mientras que los vecinos podían edificar hornos de pan, teja y ladrillo, también libres de cargas. Por otra parte, la carta puebla dada en 1310 por Fernando IV a Gibraltar incluye la supresión del diezmo, portazgo, alcabala, montazgo, servicio, rolda, asadura, castillería y otros derechos, así como de los impuestos de las viandas acarreadas para su abastecimiento. Ese mismo año el rey amplió la gracia dada por su padre a Medina Sidonia (1288) con la eliminación del pago de alcabala, algo similar a lo ocurrido en la cercana Alcalá de los Gazules, a cuyos habitantes Alfonso XI también redimió, en 1342, de portazgo, almojarifazgo, roda, castillería, pasaje, peaje y barcaje de aquello que allí llevasen para su avituallamiento. En 1344, la feria de Tarifa quedó libre de portazgo y almojarifazgo. Y, en 1345, Medina Sidonia de la alcabala real. El último de estos tres privilegios fue confirmado por Pedro I (1350) y el primero lo extendió Enrique III a los habitantes de Arcos de la Frontera, a partir de 1399, y lo aumentó con exención asimismo de alcabalas reales, para que gozasen de iguales ventajas que los de Alcalá, Medina y Tarifa, que estaban libres de diezmo, portazgo, veintena, cuarentena, alcabalas y otros derechos, de entrada o de salida, por mar o tierra. Según consta en un pleito que se desató hacia 1402 ante el alcalde de la aduana de Jerez de la Frontera, entre la villa de Arcos y los almojarifes xericenses.

El citado litigio estuvo motivado en la reivindicación de la mencionada localidad, apoyada en dicho privilegio real, del derecho de sus vecinos a pasar libremente con mercancías y sus mantenimientos, y sin informar a los almojarifes, por el camino que venía desde Medina Sidonia y por el que iba a Sevilla y a Alcalá de los Gazules, que atravesaban el término jerezano, el cual no les era respetado por éstos. Este proceso fue ganado por el concejo arcobricense. Del mismo modo, en el primero de los cuadernos del almojarifazgo de 1497 dado por la duquesa de Arcos a esta ciudad sede principal de sus señoríos, que veremos más abajo, se dice que si los vecinos de ésta llevaban sus mercancías a vender a Jerez u otras partes de la comarca, tanto estos vendedores como los compradores locales no debían abonar nada al almojarife arcense; pero si la venta tenía lugar en el término de Arcos debía ser comunicada al mismo para hacerle entrega de su derecho del 5\%, una vez cobrado por el vendedor al comprador. Por último, en 1370, Enrique II, a petición del concejo de Osuna, propiedad de la orden de Calatrava, y en atención a su situación fronteriza, eximió a sus vecinos del pago de alcabala y otros derechos de lo que allí llevasen para su sustento, merced de la que gozaban los restantes 
castillos de la conocida por entonces como banda morisca, o limítrofes con las tierras granadinas. Se podía entender entonces que, como aquéllos, Osuna habría disfrutado también de franqueza de portazgo, almojarifazgo y demás rentas que no pagaron los moradores de las localidades más arriba referidas. Sin embargo, este extremo no parece tan claro ya que, en 1378, dicho monarca, tras hacer retornar Morón de la Frontera al realengo, antes en posesión de la orden de Alcántara, le concedió las libertades de las que gozaban Utrera y Osuna, que consistían solamente en la redención de las alcabalas de los productos que llevasen a la villa para su provisión y mantenimiento. Nada se dice, sin embargo, de otros derechos, señal de que comenzaban a restringirse los extraordinarios márgenes de privilegio y de rebaja de la presión fiscal a estas poblaciones de la vanguardia militar ${ }^{15}$.

En 1448, Juan Ponce de León, II conde de Arcos, puso en arrendamiento las rentas de su villa de Rota para el trienio 1449-1451. Entre ellas se encontraba la almadraba local, que desconocemos si alguna vez estuvo comprendida en el almojarifazgo. Lo que sí sabemos es que los trabajadores de dicha instalación pesquera, como los de las restantes almadrabas de la Casa, estaban exentos de abonar derechos por los productos, incluidos paños, que a ellas eran llevados para su consumo. Sin embargo, algunas de tales mercancías eran posteriormente revendidas a los vecinos del lugar de forma fraudulenta, sin satisfacer las cargas correspondientes, lo que perjudicaba a la hacienda condal. Por ello, el señor dispuso que el género llevado a la almadraba debía ser registrado por el arrendatario de sus rentas antes de ser descargado, para que cobrase alcabala y almojarifazgo de lo que no fuese destinado a ella ${ }^{16}$.

\section{Tipología DE RENTAS}

En estos almojarifazgos de la baja Andalucía del siglo XIII, como ocurrió en Toledo, Sevilla, Córdoba o Murcia, además de los relictos del diezmo islámico, o diezmo real antedicho, y de las exacciones aduaneras sobre el tráfico comercial, se habrían incluido una gran diversidad de rentas que gravaban otros supuestos y actividades económicas, de las que solamente tenemos noticias a veces indirectas o poco precisas. Si bien cada localidad reunió una cantidad y variedad propia de derechos en su almojarifazgo, si comparamos los habidos en las 4 grandes capitales susodichas se puede apreciar cómo algunos de ellos influyeron en el fisco de

15. En 1411 los ejecutores de Sevilla ordenaron a las justicias de su jurisdicción respetar las exenciones de los habitantes de Medina Sidonia. AHN, SN, Osuna, caja 116, documento 43; caja 120, documentos 2-3. M.A. Ladero y M. González. "La población...”, pp. 230-233, 237-247; M. González Jiménez. Diplomatario, pp. 531-532; M.A. Ladero Quesada. Los señores, pp. 359-364, 370-384, 397-398, 456-457; M. García Fernández. El reino, pp. 16, 19-20; M. García Fernández. "La villa de Osuna entre Pedro I y Enrique II: algunas reflexiones sobre la guerra civil castellana en Andalucía (1366-1371)". HID, 31, 2004, pp. 221-225. En 1285, Sancho IV eximió a Jerez de la Frontera, como ocurrió con sus localidades vecinas, del pago de portazgo y diezmo (almojarifazgo aduanero) de todo lo que llevasen para su abastecimiento y de la producción local (J.D. González Arce. "Actividad...”).

16. AHN, SN, Osuna, caja 1.633, documento 5. 
las otras. De manera que, por su semejanza, se puede plantear la hipótesis de que fueron imitados en su día por sus respectivos emires musulmanes o más adelante por los monarcas castellanos, que los habrían trasvasado entre tales plazas junto con el marco foral y el resto del derecho local. Esto nos permite presuponer que habría ocurrido algo semejante con los almojarifazgos locales de las poblaciones del reino de Sevilla durante el siglo XIII que, por su proximidad geográfica y por las circunstancias de su conquista y repoblación, también tendrían que haber sido parecidos. Comprobémoslo.

\subsection{El almojarifazgo de Arcos de la Frontera}

En 1279, los mercaderes de Burgos se quejaron ante Alfonso X porque en la villa de Arcos de la Frontera les cobraban ciertas alcabalas de los productos que allí introducían. Éstas serían parecidas a unas veintenas llevadas en Jerez (tasas del $5 \%$ sobre la carne, pescado, fruta, caza, esparto y labores de barro, así como terzuelos de la grana, aceite y salvajina...), cuando, según ellos, estaban exentos gracias a los privilegios concedidos por Alfonso VII, confirmados por el Rey Sabio. Por su parte, los arcobricenses alegaron que la exigencia de dichas alcabalas les había sido otorgada por el propio Alfonso X mediante otro privilegio, que les permitía exigirlas tanto a los forasteros como a los vecinos. El monarca, si bien consintió que se mantuviese este estado de cosas, amparó a los burgaleses, que no deberían en adelante satisfacer el tributo ${ }^{17}$. Estas tasas del siglo XIII sobre la compraventa en forma de quincenas, veintenas o cuarentenas, de clara herencia musulmana, fueron luego denominadas alcabalas viejas para diferenciarlas de la alcabala real implantada en toda la Corona a mediados del siglo XIV por Alfonso XI, que se inspiró en aquéllas. Formaban parte de lo que el profesor Ladero Quesada denomina como una fiscalidad tradicional menor o primitiva, de origen islámico, restos de antiguos almojarifazgos o tesorerías de época almohade ${ }^{18}$.

En 1333, la localidad fue entregada a Sevilla, aunque mantuvo sus privilegios y obtuvo nuevas franquezas y mercedes en atención a su carácter fronterizo. Entre ellas, la cesión al concejo arcense de todo su almojarifazgo, cuyo rendimiento quedó distribuido de la siguiente manera: $7.200 \mathrm{mrs}$. con destino a rondas y velas, y el resto para la reparación de las murallas. Este último extremo dejó de ser observado tras pasar a ser villa de señorío, a comienzos del siglo $\mathrm{XV}$, de manera que sus titulares arrendaron la renta sin destinar lo estipulado a la conservación de la cerca ni del castillo, aunque sí respetaron las rondas. Las condiciones de dicho arrendamiento fueron fijadas en 1409 por Ruy López Dávalos, condestable de Castilla y duque de Arjona, a quien pertenecía la renta, y luego renovadas en 1413 y 1421. Entre ellas, las relativas a la compraventa de productos, por la que los no vecinos debían pagar al almojarifazgo el 2,5\% de su precio, salvo de aquello que estuviese ya gravado con veintena $(5 \%)$ o cuarentena $(2,5 \%)$, tipos, que a buen seguro, co-

17. AGS, CC, Diversos, 4, 101. J.D. González Arce. “Actividad...”.

18. M.A. Ladero Quesada. Los señores, p. 59. Sobre los orígenes de las alcabalas castellanas, del mismo autor, "Los primeros pasos de la alcabala castellana, de Alfonso X a Pedro I". AEM, 22, 1992. 
rrespondían a las antedichas "alcabalas viejas". A la importación por forasteros de ropa confeccionada se le exigía también veintena, y a la exportación, cuarentena. Los textiles y otras mercancías introducidas, antes de ser descargadas, debían ser mostrados al arrendatario de la renta en la aduana o en su casa. Los lugareños que vendiesen artículos (paños, aceite, cereales...) a extraños debían recaudar la exacción de éstos para dársela al almojarife. Los vecinos, por la saca de ganado a pastar a tierra de moros abonarían veintena, un canon de 1 de cada 20 cabezas, o su equivalencia en dinero, amén de castillería. Si las reses adquiridas por los del lugar eran compradas fuera del término o a foráneos para exportarlas a Granada, debían dar en la villa el medio diezmo (de lo morisco) al arrendatario de su almojarifazgo. En materia de pesos y medidas, se remitía a lo actuado en los años previos. El señor y su almojarifazgo percibirían $1 / 5$ de las cabalgadas, y el 2,5\% de lo obtenido en éstas por los participantes ajenos a la villa. Habría una correduría única para la venta de las joyas metidas por los musulmanes. Además, existió una correduría de saca de paños, que se arrendó en 1422, aparte del almojarifazgo local. En 1429 Arcos retornó al realengo, circunstancia aprovechada por Juan II para confirmar la cesión susodicha de los $7.200 \mathrm{mrs}$. y de la cantidad restante para la conservación de las murallas, posteriormente ratificada en 1430 y $1432^{19}$.

En 1497, la ciudad pertenecía a los Ponce de León. Ese año y el siguiente la duquesa viuda, Beatriz Pacheco, dispuso nuevas normas en dos cuadernos de arrendamiento de su almojarifazgo, pues algunas de las anteriores ya no eran precisas o habían variado. Es el caso de las condiciones referidas al portazgo, cuyo arancel había sido renovado por los Reyes Católicos, dentro de una reforma de los derechos de paso de toda Andalucía emprendida entre 1490-1492. Mientras que estaban de más las cláusulas que regulaban el comercio con tierras musulmanas, tras la toma de Granada. En los nuevos documentos se mantiene el arancel del 5\% sobre el valor de las compraventas de los extranjeros, el cual debía ser justipreciado por una o dos personas entendidas, así como los otros aspectos sobre el pago del mismo, sobre los ganados y sobre el uso de pesos y medidas, igualmente en función de la costumbre. No obstante, se aclara que la media fanega para medir el pan la podía tener cualquier vecino o morador labrador, para vender o medir trigo o cebada, aunque no fuesen suyos, sin pagar cozuelos (tasas en especie por la utilización) algunos, por cuanto el conde Pedro Ponce había hecho donación de estas medidas a Arcos, siempre que se empleasen correctamente y tras ser marcadas por el almotacén; si no se tuviese tal medida, se podía tomar de otro vecino, a cambio de pagar al almotacén su derecho de $4 \mathrm{mrs}$. por su uso. El aceite debía ser vendido con la media arroba del almojarife, tras abonarle 1 blanca por cada arroba mensurada. También se recogen los derechos por utilización del peso del almojarife, que debían abonar todos, vecinos y forasteros (tabla 1), pues el almotacenazgo local estaba incluido en el almojarifazgo.

19. AHN, SN, Osuna, caja 116, documentos 44-47, 50-51, 55; y, carpeta 65, documentos 22 y 24. J.L. Carriazo Rubio. "Notas sobre fiscalidad señorial: el almojarifazgo de Arcos de la Frontera a comienzos del siglo XV". En IV Coloquio de la Red Arca Comunis, Agentes de los sistemas fiscales en Andalucía y los reinos hispánicos (siglos XIII-XVII), Málaga, mayo de 2013. 
En una gran cantidad de localidades andaluzas la fabricación de jabón solía ser un monopolio en manos del concejo o de sus respectivos señores, que era arrendado al mejor postor. Sin embargo, no está claro que formase parte de los almojarifazgos concejiles o señoriales, cosa que sí ocurrió en Arcos, donde en ocasiones el almojarife pudo subarrendar dicha producción, según se desprende de las condiciones de 1497; además, el antedicho podía dar licencia para su elaboración a los vecinos, que podían introducir en la localidad hasta una libra de jabón para su consumo familiar. Algo parecido ocurrió con el lino, pues estaba prohibida su venta entre lugareños sin licencia del almojarife. Los ballesteros de monte y los restantes arcobricenses estaban exentos por la caza que vendiesen en la ciudad, igualmente por concesión del conde Pedro. Los forasteros que poseyesen en ella bienes raíces, cuando los enajenasen debían satisfacer a los arrendatarios del almojarifazgo la veintena (5\%) sobre el precio de venta. Del mismo modo, se contienen las tasas a abonar por los extranjeros por la compra de ganados locales. Además del 5\%, pagarían las siguientes cuantías: por cada res vacuna, $2 \mathrm{mrs}$; puerco, $1 \mathrm{mr}$. y 1,5 cornados; cochino (¿lechón?), 1 blanca y 1,5 cornados; carnero, oveja, cordero o cabra, 2 cornados; caballo, yegua u otra bestia, 2 mrs. En el segundo cuaderno de 1498 se recogen las imposiciones exigidas a los ganados de fuera o albarranes que llegasen a herbajar: 50 mrs. por cada res mayor (vacas, bueyes, equinos...), y 15 de cada res menor (ovejas o cabras). En esta localidad había también una renta de las cuatro tiendas, arrendada junto con su almojarifazgo y la tienda de la plaza ${ }^{20}$.

Tabla 1: Derechos del peso del almojarifazgo de Arcos de la Frontera (1497)

\begin{tabular}{|c|c|c|}
\hline Artículo & Peso & Derecho \\
\hline Lino, matalahúva, cominos, azúcar, almendra & \multirow{2}{*}{$1 @$} & 1 libra \\
\hline \multirow{2}{*}{ Lana } & & 1 blanca \\
\hline & 1 libra & 3 cornados \\
\hline Grana & \multirow{4}{*}{ 1@ } & 0,5 blancas \\
\hline Grana verde o seca & & $4 \mathrm{mrs}$. \\
\hline Sebo, unto & & $2 \mathrm{mrs}$. \\
\hline Higos, pasas, bayo, casca & & 1 blanca \\
\hline Hierro, acero & 1 quintal & $2 \mathrm{mrs}$. \\
\hline
\end{tabular}

20. AHN, SN, Osuna, caja 120, documentos 2-3. Como en Arcos, en su vecina Zahara (de la Sierra), también perteneciente a los Ponce de León, existió un almojarifazgo sobre el tráfico comercial (E. Solano Ruiz. "La hacienda...", pp. 87-96, 156-168). Esta autora refiere mal el canon del almojarifazgo aduanero y el pagado por los ganados, habla de un tipo del 3\% cuando, como hemos visto, era del 5; sin embargo, éste aparece bien transcrito en el apéndice documental $\mathrm{n}^{\circ} 2$ de su trabajo. 


\subsection{El almojarifazgo de Morón de la Frontera}

Morón de la Frontera vivió una situación paralela a la de Arcos de la Frontera, hasta el extremo de que la normativa de sus almojarifazgos podría haber tenido una inspiración común. No en vano, fueron localidades vecinas con unos orígenes similares. Tal y como vimos, al igual que ocurrió con Arcos, Morón fue entregada en 1253 a Sevilla, que al no poder mantenerla la retornó la Corona, para ser luego cedida, en 1279, a la orden de Alcántara. Tras regresar brevemente al realengo con Enrique II, y volver otra vez a poder de dicha orden, en 1387 el comendador de la villa, frey Pedro de Morales, y su concejo acordaron un nuevo arancel para la recaudación del almojarifazgo local, pues en el vigente hasta entonces, de tiempos del anterior señor, Enrique Enríquez, hijo extramatrimonial del citado rey, se habían introducido novedades y exigencias que agraviaban a los vecinos. El nuevo padrón debía contener los usos y derechos tradicionales en esta materia, cobrados por los anteriores comendadores, o por sus almojarifes, en tiempos del maestre Fernán Ponce de León (1346-1355). Además, como ocurrió en otros casos con este tipo de normativa, aparecen entremezcladas disposiciones que no tienen nada que ver con la materia fiscal, aunque sí con algunas rentas jurisdiccionales percibidas por los señores. Por ejemplo, las penas a cobrar por el alguacil en las peleas con derramamiento de sangre, homicidios o carcelajes ${ }^{21}$.

Si comenzamos por los pesos y medidas, como en Arcos, los vecinos podían tener sus medias fanegas señaladas por el almotacén para la venta del trigo, cebada o legumbres de su cosecha, así como de la mies de las rentas de los bueyes, molinos, aceñas o terrazgos. Dichas medidas no se podían alquilar o prestar a nadie, de forma que aquel que careciese de ellas había de usar la del almojarife, al que debía abonar la tasa correspondiente de 1 cuartillo por fanega mensurada. No obstante, en los préstamos de grano en especie sin beneficio se podía utilizar la fanega propia u otra cualquiera, sin pagar nada; aunque si el préstamo era en dinero o con ganancia, se debía informar al almojarife, para que percibiese su derecho, siempre que no se emplease una medida propiedad del prestamista. Los arrendatarios de las aceñas, molinos o tahonas que debían satisfacer el alquiler en especie no podían vender género con la media fanega ni el almud de la instalación alquilada, sino con los del almojarife; sin embargo, los arrendadores propietarios sí podían usar sus medidas para comercializar lo recibido en renta si eran vecinos de la villa. Por lo que respecta a la venta de aceite, solo se podía usar la arroba del concejo, aunque los forasteros debían abonar por ello veintena (5\%) al almojarife. No obstante, si era entregada aceituna a cambio de aceite, la medición se podía hacer con la arroba del molino, si bien este óleo luego solo se podía vender con la arroba del concejo; en cambio, si la renta se pagaba en dinero, se tenía que comunicar al almojarife este extremo, como en el caso anterior de préstamo de cereal en dinero o con ganancia, por lo que se deduce que en este caso se le pagaría la antedicha

21. M. González Jiménez. "Privilegios de los maestres de Alcántara a Morón de la Frontera", AH, 70, 214, 1987, pp. 3-6, 10-29; M. González Jiménez y M. García Fernández. Actas capitulares de Morón de la Frontera (1402-1426). Sevilla, 1992, pp. 24-35. 
veintena, como hacían los de fuera o los regatones importadores. Nadie podía tener peso en su casa para las compraventas, pues ninguno estaba libre de satisfacer este derecho, salvo los ballesteros de monte o cazadores de grandes piezas. Por el uso de este peso monopolista propiedad del concejo se abonaban al almojarife las siguientes tasas: comprador y vendedor, cada uno, de 1@ de lino o de lana, 1 dinero; de 1 de cera, 11 sueldos; de 1 libra de cera, 1 sueldo; y, sin especificar si comprador o vendedor, 1@ de algodón,6 sueldos.

La compra de equinos locales por gente de fuera estaba gravada, como en Arcos, con la veintena, pero en este caso era el vendedor el que además debía dar 1 mr. por cada cabeza mayor y 5 dineros por la menor; mismas tasas a entregar por los vecinos, es de suponer que por la compra de dichas bestias. Si los cuadrúpedos eran cambiados unos por otros estaban exentos, pero sí se abonaría el canon correspondiente por las cabezas mayores y menores, como los vecinos del lugar. Si se hacía el intercambio con ganado o heredades, tras ser apreciados los équidos, estaban sujetos a dicha tributación, ad valorem y por cabezas, según el precio estimado. Si los locales vendían dichos animales a musulmanes, los primeros debían correr con el pago de las cabezas y los segundos con el del diezmo y medio diezmo (de lo morisco). En cuanto a la compraventa de ganado por los no lugareños, las cargas eran de $2 \mathrm{mrs}$. por cabeza de vaca/buey, 2,5 dineros por la de carnero/ cabrón/cabra, 5 por el puerco y 1 por el cordero/cabrito. Los bovinos criados o comprados y mantenidos más de un año por los vecinos estaban libres; si no era así, pagarían 7,5 dineros por su venta. Todos los que adquiriesen algún ganado para venderlo fuera del pueblo debían satisfacer las tasas antedichas. Los foráneos tenían que dar 5 dineros por cada cerdo llevado a vender; de los que eran francos los vecinos, siempre que jurasen que era de su crianza o lo habían comprado.

En cuanto a la carne, la cortada en la carnicería concejil estaba sujeta a tributación dentro de este almojarifazgo señorial: por cada vaca/buey (incluidos los de los vecinos muertos en el arado), las primeras 5 libras pesadas; carnero/oveja/ cabrón/cabra/gama, 1 libra; ciervo macho, 4; de la cierva/jabalí, 2; puerco manso, 0,5. En otros lugares, esta gabela en especie, también llamada renta de las libras de la carne, se transformó en una acabala ad valorem, generalmente del 5\%, más fácil de percibir. Los cazadores lugareños de conejos debían entregar al almojarife 1 de cada 10 vendidos.

A diferencia de los diezmos del barro vistos más arriba, destinados a obras edilicias, en Morón los hornos de ladrillo, teja y toda labor cerámica tributaban al almojarife dicho $10 \%$, siempre que la producción se destinase a la exportación (saliere a puerto); mientras que de la labor vidriada se pagaba veintena; y del vidrio, también diezmo. Como en otras partes, la fabricación de jabón estuvo sujeta a régimen de monopolio, en este caso al menos parcial, pues el almojarife debía dar licencias a los forasteros para producirlo o venderlo. El mismo se encargaba también de los musulmanes y tártaros cautivos hallados en el término concejil. Si tenían dueño debían ser entregados a dicho almojarife, quien recompensaría al que los había encontrado con 100 mrs. por cabeza; es de suponer que luego él cobraría las correspondientes tasas del propietario. Si dichos cautivos no lo tenían, el que 
los hallaba contaba con derecho a $1 / 3$ de su valor y el almojarife al resto, es de suponer que tras ser vendidos. En cualquier caso, este último debía correr con las costas del alguacil y de las prisiones por las que hubiesen pasado.

Como en los restantes lugares, en términos generales los vecinos estaban exentos por todo lo que comprasen o vendiesen, con alguna excepción, como hemos visto y veremos; también lo estaban por los tratos hechos con otros vecinos, aunque si los tenían con forasteros debían hacerlo saber al almojarife. Como en Arcos, la importación de mercancías estuvo gravada con una tasa genérica del 5\%, la famosa veintena o alcabalas de otros lugares. Así, según el apartado 24 de este arancel del almojarifazgo moronense (disposición que se repite en el 50), todos los cristianos, moros o judíos extraños debían correr con la veintena y otros derechos pertenecientes al almojarifazgo, tanto del barro como por la madera labrada o por labrar (luego, la cláusula 27 vuelve monográficamente sobre este tipo de bienes), como de otras cosas de buhonería o de alcaçería; también habían de comunicar sus cargamentos al almojarife o arrendatario de la renta antes de ser abiertos para su venta. Más adelante, el siguiente epígrafe, insiste en que los foráneos, y foráneas, que llevasen a comerciar paños, lienzos, sayales, lana, queso u otras cosas satisficiesen todos sus arbitrios al almojarife, que también cobraría derechos por la bellota, nuez, castañas, demás frutas secas, especería, ajos, etc. Según un título específico, la importación de pescado de todo tipo por los no vecinos estaba cargada igualmente con la veintena. Lo mismo que disponía otro para la introducción de conejos (por su carne o piel) y pájaros -a excepción de palomas, tórtolas o zorzales, que estaban exentos-; pero, si los lugareños los cazaban fuera del término y luego los introducían en él darían cuarentena $(2,5 \%)$.

Sin embargo, algunos productos importados resultaron sujetos a una tributación especial, a pagar tanto por el comprador como por el vendedor, según se recoge más abajo en la tabla 2 y posteriormente:

Tabla 2: Artículos sujetos a tributación especial a pagar por cada arroba en el almojarifazgo de Morón de la Frontera (1387)

\begin{tabular}{|l|l|l|l|}
\hline Artículo & Tasa & Artículo & Tasa \\
\hline Cebollas & 1 dinero & Pasas & 5 sueldos \\
\hline Jengibre y bayón & 5 dineros & Cominos, alcaravea y añil molido & 6 sueldos \\
\hline Azafrán & 12 dineros & Unto & 9 sueldos \\
\hline Higos & 1 sueldo & Pimienta, canela y orozuz & 12 sueldos \\
\hline Sebo y casca molida & 2 sueldos & Azúcar & $1 \mathrm{mr}$. \\
\hline Hierro, greda y queso & 3 sueldos & Seda & $2 \mathrm{mrs}$. \\
\hline
\end{tabular}


La grana comprada por los vecinos estuvo gravada con 2/9; la cogida por los forasteros, con el 10\%, más 11 sueldos por arroba si la vendían o la compraban. La salvajina adquirida, vendida o transportada por los foráneos, cotizaba: cuero vacarí, 2 mrs.; becerril, 1; cabruno cerrado, 2 dineros; pellejo carneruno cerrado, 2 sueldos, abierto, 1; corderina, 3 meajas; vestido conejuno, $1 \mathrm{mr}$.; cada jineta, garduña, zorra, nutria, 2,5 dineros; encorada de ciervo macho, 4 dineros, hembra, 2; gamo macho, 3, hembra, 2; gato montés, 1; cerval gatuno, 2; cuero cerval, 4; gato de fuego y liebre, exentos. Si los forasteros compraban para exportar alguno de estos bienes pagarían solo la mitad de la contribución. Los antedichos, por la introducción de cera abonarían 4 mrs./@y 2 por sacarla; en el caso del lino, lana y otros géneros vendidos al peso o sin peso, darían veintena de entrada y cuarentena de salida; por el vino de fuera, 8 dineros por carga mayor y 4 por la menor; y, por cada colmena, 1 cornado de entrada, otro de salida y el 10\% de las castras hechas en el alfoz. En el título 39 se habla de las cargas cerradas de paños, sayales, buhonería, especiería, ajos... transportadas también por los no vecinos. Éstos debían pagar por ellas, es de suponer que por su tránsito por la localidad, $6 \mathrm{mrs}$. por la mayor y la mitad por la menor; también 6 mrs. pagarían por el moro herrado (cautivo) de paso; y por los potros, yeguas encabestradas merchantes y mulos/as encabestrados/as; mientras que por los puercos, ovejas, carneros, cabrón y cabra darían 5 dineros; y, por las reses vacunas, $2 \mathrm{mrs}$., igual que por el paso de éstas hacía tierra de moros; aunque las ovejunas abonaban 5 dineros y las cabrunas 2,5. Por el tránsito de cargas de sogas o esparto, hacia cualquier parte, se entregarían 4 dineros por unidad.

\subsection{El almojarifazgo de Niebla}

En las Cortes de 1268 Huelva fue designada como puerto aduanero, aunque el almojarifazgo de las mercancías que por allí transitasen se cobraría en la aduana de Niebla. Dicho arancel rentó a la Corona algo más de 17.000 mrs., según las cuentas de 1294, frente a los 22.500 del cobrado en Jerez de la Frontera o los 450.000 de Sevilla. Se trató de un gravamen sobre las importaciones del 10\%, o diezmo, que fue eximido en la feria franca dada a Niebla por Alfonso XI, en 1336, confirmada en 1348, si bien la primera concesión databa de 1287. Los pleitos sentenciados por el alcalde de esta aduana lliplense (o iliplense) solo tendrían apelación ante los alcaldes locales, y no ante los de la aduana hispalense. En 1310 fueron embargados los bienes de propios del municipio, entre los que ya se contaban los almojarifazgos que la villa cobraba en sus aldeas, como lo hacía Sevilla con las suyas, hasta que ésta contribuyese con su parte al abastecimiento de Gibraltar. Años más tarde, 1327, Alfonso XI incorporó a este almojarifazgo concejil el de otros lugares para ayudar en la reparación de la fortaleza. Al año siguiente le concedió Moguer, aunque el monarca se reservó su almojarifazgo durante 6 años.

En 1338, Niebla arrendó por 8 años y 42.000 mrs. (de a 3 dineros el maravedí) los derechos comprendidos en su almojarifazgo concejil a Domingo Martín de Aguilar, sevillano de la collación de Santa María Magdalena, Ferrán Pérez de Mo- 
guer, de la propia Niebla, de la collación de Santa María, Sisa Aben Aladeb, Zag Scatiel, Moisés Bruaño, Francisco Fernández, escribano del concejo de Sevilla, y David Aben Sey. Se trató de los derechos percibidos en las aldeas y lugares del municipio -Villalba (del Alcor), La Palma (del Condado), La Torrecilla, Beas, Trigueros con el Caserío de Pedro Caro, Bonares y Rociana (del Condado)-, junto con el montazgo, que también pertenecía a los bienes de propios, licitado por 1.000 mrs. anuales. El mayordomo del consistorio quedaba a cargo de librar los pleitos que surgiesen al respecto, mientras que un vecino, Per Yáñez, atendería las apelaciones. El dinero se destinaría a pagar a Martín Fernández de Portocarrero (IV señor de Moguer) parte de los 60.000mrs. que le debía Niebla por la compra de la antedicha aldea de Villalba, según había dispuesto el rey. Tras la conversión de Niebla en condado bajo titularidad de la Casa de Guzmán, en 1369, los nuevos señores arrebataron a los propios municipales los almojarifazgos de sus aldeas, restituidos nuevamente en 1386 una vez reconocida su incorrecta apropiación. A comienzos del siglo XVI, en Niebla existía una renta de los paños y ferias, que, como veremos que ocurrió en Palos, sería una desagregación del almojarifazgo local, esto es, un derecho sobre el tráfico comercial específico para esta clase de artículos textiles, así como para los llevados a la feria, que entre 1509-1511 ascendió a unos $45.000 \mathrm{mrs}$. anuales. También en Trigueros había otra renta de los paños, de en torno a 9.000. Mientras que en Huelva estaba la renta de los paños de feria $(30.000)$ y la de los sayales $(8.500)^{22}$.

Los almojarifazgos aldeanos arriba vistos probablemente serían similares a los de otras poblaciones, esto es, incluirían alcabalas viejas. Como ocurría en la vecina Gibraleón, villa en la cual el duque de Béjar poseía, entre muchas otras, las denominadas rentas mayores, arrendadas en bloque. Entre las que se comprendían, como en Cartaya, las alcabalas reales (por las que el señor pagaba a la Hacienda regia $15.000 \mathrm{mrs}$. anuales, de ambas localidades), el almojarifazgo aduanero (que el aristócrata tenía por propio, recibido con el resto de los derechos del señorío), la antedicha alcabala vieja, teja y ladrillo (el diezmo más arriba visto), etc. En este sentido, cuando Gibraleón fue enajenada de la Corona por Pedro I en favor de su hijo Fernando, en 1361, la donación, a buen seguro, habría incluido todos los pechos y derechos reales; almojarifazgo, portazgo, aduanas, alcabalas y ferias, entre ellos. Por su parte, Cartaya obtuvo a comienzos del siglo XVI exención de almojarifazgo por las capturas de pescado hechas por sus vecinos, a excepción de los cazones y sábalos provenientes de Guinea ${ }^{23}$.

22. AGS, Medina Sidonia, 3, 29. J.M. Navarro Sáinz. “Aspectos económicos de los señoríos de los duques de Medina Sidonia a principios del siglo XVI”. HH, 2, 1988, pp. 341-342. En 1331, Alfonso XI también retuvo el almojarifazgo de Villalba, que, como acabamos de ver, acabó integrado en el almojarifazgo concejil lliplense (M.A. Ladero Quesada. Niebla, pp. 31-32 41-47, 65, 70; M. García Fernández. El reino, p. 164).

23. AHN, SN, Osuna, caja 380, documento 42. M.A. Ladero Quesada. Los señores, pp. 132-155. M.C. Quintanilla Raso. "La reglamentación de una villa de señorío en el tránsito de la Edad Media a la Moderna. Ordenanzas de Cartaya (Huelva)". HID, 13, 1986, pp. 203-204. 


\subsection{El almojarifazgo de Sanlúcar de Barrameda}

Se ha conservado una relación remitida a la real Hacienda por los contadores del duque de Medina Sidonia relativa a las rentas y alcabalas de Sanlúcar de Barrameda, del año 1634, cuyo rendimiento fue de algo más de 30 millones de mrs. A partir de su análisis podemos intentar deducir qué exacciones compusieron su almojarifazgo medieval ${ }^{24}$.

En primer lugar, sin duda, el gravamen aduanero, que, como es sabido, fue la única cesión legal de la monarquía a un señor territorial del almojarifazgo costero, o derecho del cargo y descargo de la mar, que los duques podían exigir de las mercancías que arribasen o partiesen del puerto de su villa. En el siglo XVII se cobraban a dichas mercancías, en la aduana de Sanlúcar, tanto el almojarifazgo como la alcabala de la primera venta, como en Sevilla, y luego se daba cuenta de lo recaudado a las contadurías reales. De este modo, el citado año 1634 todo ello sumó casi 6,5 millones de mrs. Otras punciones consistieron en alcabalas y otras rentas, similares a las antedichas alcabalas viejas vistas para otros lugares, equivalentes, por tanto, a las rentas menudas del almojarifazgo de Sevilla (tabla 3).

Tabla 3: Alcabalas y otras rentas de Sanlúcar de Barrameda (1634), en origen probablemente pertenecientes a su almojarifazgo

\begin{tabular}{|c|c|}
\hline CONCEPTO & TASA \\
\hline \multicolumn{2}{|c|}{ ALCABALA DE LA CARNICERÍA* } \\
\hline \multicolumn{2}{|c|}{ ALCABALA DE LA MADERA } \\
\hline \multicolumn{2}{|l|}{ Entrada y venta de: } \\
\hline Madera foránea & $5 \%$ \\
\hline Botas abatidas, madera cruda y tripitrapes ${ }^{* *}$ & $2 \%$ \\
\hline Perruco, duelas y bornes & $3 \%$ \\
\hline Arcos y mimbres & $2 \%$ \\
\hline Botas seisas, barriles cuartos y toneles & $10 \%$ \\
\hline
\end{tabular}

* Cobrada por la carne en ellas sacrificada y pesada. Aunque no sabemos en qué consistieron, hemos visto que en Morón se percibió en especie, mientras que en la vecina Jerez de la Frontera sus libras de la carne o alcabala vieja de las carnicerías acabó por convertirse en una acisa del 5\%. Para los restantes apartados que aparecen sin contenido tampoco se especifica en el documento en qué consistía la renta en cuestión.

** En inglés coloquial, montón de viejos muebles y madera.

24. AGS, PR, legajo 37, 8 . 


\begin{tabular}{|c|c|}
\hline \multicolumn{2}{|l|}{ Venta a forasteros para afuera o a los vecinos: } \\
\hline Bota & 0,5 reales \\
\hline Tonel & 1 real \\
\hline Cuarto & $8 \mathrm{mrs}$. \\
\hline \multicolumn{2}{|l|}{$\begin{array}{l}\text { Tablas de altamar u otras partes, mástiles, berlingas, palas, escudillas, } \\
\text { tornillos de palo, cabos de azadones, sillas de palo, entrada y venta: }\end{array}$} \\
\hline & $4 \%$ \\
\hline Forasteros & $3 \%$ \\
\hline $\begin{array}{l}\text { En la feria } \\
\text { Comprados y vueltos a vender }\end{array}$ & $2 \%$ \\
\hline \multicolumn{2}{|l|}{ Pez, resina rasa, alquitranes, estopa, lino, lana y linternas, entrada y venta: } \\
\hline Vecinos & $4 \%$ \\
\hline Forasteros & $3 \%$ \\
\hline \multicolumn{2}{|l|}{ ALCABALA DEL ACEITE } \\
\hline \multicolumn{2}{|l|}{ Vecinos, venta minorista: } \\
\hline Almojarifazgo de entrada & $5 \%$ \\
\hline Alcabala & $10 \%$ \\
\hline Uso de arrobas y cuartas & $20 \mathrm{mrs}$. \\
\hline \multicolumn{2}{|l|}{ Forasteros, venta minorista sin almacenamiento: } \\
\hline Almojarifazgo de entrada & $5 \%$ \\
\hline Alcabala & $10 \%$ \\
\hline Exportación por tierra o paso por la localidad, por @ & 4 mrs. \\
\hline \multicolumn{2}{|l|}{$\begin{array}{l}\text { Importación por mar para almacenamiento o reexportación, en toneles y } \\
\text { pipas, derecho de la aduana }\end{array}$} \\
\hline \multicolumn{2}{|l|}{ ALCABALA DE REVENTA DE PAÑOS Y SEDAS } \\
\hline \multicolumn{2}{|l|}{ ALCABALA DEL PESCADO FRESCO Y SALADO } \\
\hline \multicolumn{2}{|l|}{ Toda suerte de pescado: } \\
\hline Almojarifazgo de entrada & $5 \%$ \\
\hline Alcabala & $10 \%$ \\
\hline Reexportado sin vender & $2,5 \%$ \\
\hline
\end{tabular}




\begin{tabular}{|c|c|}
\hline Capturas con cordel: & \\
\hline 13 peces & 2 piezas \\
\hline $100 \mathrm{mrs}$. & $14 \mathrm{mrs}$. \\
\hline Autoconsumo & Exento \\
\hline 12 pescadas ceciales, bacalaos u otro pescado salado & 1 pieza \\
\hline $\begin{array}{l}\text { Cazoneros y chinchorreros pescadores del término, para venta local o } \\
\text { exportación }\end{array}$ & $1 \%$ \\
\hline ALCABALA DE LA ALHÓNDIGA & \\
\hline Trigo, cebada, garbanzos, habas, legumbres y semillas, venta y medición & \\
\hline Vecinos & $10 \%$ \\
\hline Forasteros: & \\
\hline Carretada de 1,5 cahíces & 3 reales \\
\hline Carga mayor & 1 real \\
\hline Carga menor & $25 \mathrm{mrs}$. \\
\hline Caroa de harina & $20 \mathrm{mrs}$. \\
\hline Carga de harina, reventa & $5 \mathrm{mrs}$. \\
\hline Vecinos y arrendatarios del diezmo de Trebujena, vino: & \\
\hline Venta del local o del importado, alcabala y almojarifazgo & $12,5 \%$ \\
\hline Exportación & $10 \%$ \\
\hline ALCABALA DE LA PLAZA DE LA ADUANILLA & \\
\hline Madera importada de Portugal y de Niebla & \\
\hline $\begin{array}{l}\text { Fruta verde y seca y hortalizas, de arboledas o huertas, de la local y de la } \\
\text { importada, de entrada o salida, por mar o tierra, excepto dátiles y támaras } \\
\text { (cuya entrada y primera venta se abonaba en la aduana, al } 5 \% \text { ), pero sí } \\
\text { su reventa }\end{array}$ & \\
\hline $\begin{array}{l}\text { Miel entrada por tierra, entrada, salida y reventa; la entrada por mar es de } \\
\text { la aduana, pero su reventa es de esta aduanilla }\end{array}$ & \\
\hline Aceitunas y alcaparras & \\
\hline Caza & \\
\hline Lana, excepto la de tránsito para fuera del reino, que era de la aduana & \\
\hline Ajos y cebollas importados & \\
\hline
\end{tabular}




\begin{tabular}{|c|c|}
\hline $\begin{array}{l}\text { Manufacturas locales (carpinteros, esparteros, albarderos...), las importa- } \\
\text { das tributaban en la aduana }\end{array}$ & \\
\hline $\begin{array}{l}\text { Especieros, mazoneros, joyeros, sederos, tejedores, toqueros... locales, lo } \\
\text { importado tributaba en la aduana }\end{array}$ & \\
\hline Obra de esparto, pleita, sogas... & \\
\hline Leña, carbón y paja & \\
\hline Loza y vidrio, entrada por tierra & \\
\hline Coriza & \\
\hline $\begin{array}{l}\text { Reventa (la importación y primera venta es de la aduana) de: tintes, zu- } \\
\text { maque, drogas, joyería, mercería, buhonería, obras de hierro, acero, la- } \\
\text { tón, peltre..., cáñamo, alfombras, sayales, mantas..., azúcar, confituras, } \\
\text { cecinas... }\end{array}$ & \\
\hline \multicolumn{2}{|l|}{ ALCABALA DEL JABÓN } \\
\hline $\begin{array}{l}\text { A pagar por el producido por el arrendatario del monopolio de abasteci- } \\
\text { miento. El introducido y reexportado pagaría almojarifazgo al arrendata- } \\
\text { rio. El de paso estaba exento }\end{array}$ & \\
\hline \multicolumn{2}{|l|}{ RENTA DEL GANADO VIVO } \\
\hline De todo el vendido vivo fuera del rastro, incluidos equinos & \multirow[b]{2}{*}{$10 \%$} \\
\hline $\begin{array}{l}\text { Carneros, corderos, cabras y cabritos vendidos vivos en el rastro durante } \\
\text { la pascua }\end{array}$ & \\
\hline \multicolumn{2}{|l|}{ ALCABALA DEL ALMOTACENAZGO } \\
\hline $\begin{array}{l}\text { Forasteros, carga pesada por menudo o por romana de: peros, matala- } \\
\text { húva, ajonjolí, higos y pasas (salvo los vendidos a ojo que estaban exen- } \\
\text { tos), garbanzos, habas, aceituna, castañas, avellanas, almendras }\end{array}$ & 1 libra \\
\hline $\begin{array}{l}\text { Por cada día que se almacenen dichas cargas llegadas de fuera, por mar } \\
\text { o tierra }\end{array}$ & $3 \mathrm{mrs}$. \\
\hline $\begin{array}{l}\text { Forasteros y vecinos dedicados a ello, por carga de } 3 \text { fanegas de semillas } \\
\text { que midieren }\end{array}$ & 1 almud \\
\hline Por cada día que se almacenaren, por carga & $3 \mathrm{mrs}$. \\
\hline $\begin{array}{l}\text { Del resto de cosas pesadas o medidas con en el peso del almotacén (solo } \\
\text { se podía usar ése), por cada día que se almacenasen }\end{array}$ & $3 \mathrm{mrs}$. \\
\hline $\begin{array}{l}\text { Por vara de medir paños dada por el almotacén (solo se podía usar ésa) a } \\
\text { los bretones, otros extranjeros, vecinos, esparteros y para hacer ladrillo }\end{array}$ & 0,5 reales \\
\hline $\begin{array}{l}\text { Carga de aceite, extranjeros y otros para vender por la calle a cuartas y } \\
\text { medias cuartas con las medidas del almotacén }\end{array}$ & 1 cuarta \\
\hline
\end{tabular}




\begin{tabular}{|c|c|}
\hline $\begin{array}{l}\text { Carga de miel, extranjeros y otros para vender por la calle a cuartas y } \\
\text { medias cuartas con las medidas del almotacén }\end{array}$ & 1 azumbre \\
\hline Carga de lino medida con el peso del almotacén & 1 ochavilla \\
\hline \multicolumn{2}{|l|}{ Pesos y medidas revisados por el almotacén: } \\
\hline Media fanega & $4 \mathrm{mrs}$. \\
\hline Medio almud & $2 \mathrm{mrs}$ \\
\hline Pesa & 2 1115. \\
\hline Arroba y media arroba señaladas de nuevo & $8 \mathrm{mrs}$. \\
\hline Azumbre, medio azumbre, cuartillo y medio cuartillo & 4 mrs. \\
\hline Arroba y media arroba & \\
\hline Resto de medidas pequeñas & $2 \mathrm{mrs}$. \\
\hline \multicolumn{2}{|l|}{$\begin{array}{l}\text { Todas las varas y medidas debían ser revisadas cada } 4 \text { meses, según } \\
\text { el padrón de la ciudad }\end{array}$} \\
\hline De cada panadera que amasase pan para vender, cada semana & $1 \mathrm{mr}$. \\
\hline $\begin{array}{l}\text { Barco de carbón llevado a vender, por cada } 80 \text { corchos o por cada carre- } \\
\text { tada medidos con el corcho del almotacén }\end{array}$ & 1 corcho \\
\hline Carga de vidrio llevada a vender & $\begin{array}{l}1 \text { pieza o } \\
12 \mathrm{mrs}\end{array}$ \\
\hline Cada horno de ollería & $\begin{array}{l}1 \text { pieza de } \\
4 \mathrm{mrs} \text {. }\end{array}$ \\
\hline \multicolumn{2}{|l|}{ Penas varias por ensuciar la vía pública } \\
\hline 80 peces pescados con cordel llevados a vender & 1 pieza \\
\hline Menos de 80 & Exentos \\
\hline Carga de pescado fresco o salado llevado a la pescadería o vendido fuera & 1 libra \\
\hline Cada barco o carabela de sardinas (50.000 sardinas) & 500 piezas \\
\hline $\begin{array}{l}\text { Del precio de venta del atún (excepto del de las almadrabas, que estaba } \\
\text { exento), sardina arencada, espichada blanca o embarrilada }\end{array}$ & $1 / 60$ \\
\hline \multicolumn{2}{|l|}{ RENTA DE LA ZAPATERÍA Y CURTIDURÍA } \\
\hline Obras hechas en la localidad & $5 \%$ \\
\hline \multicolumn{2}{|l|}{$\begin{array}{l}\text { Calzado traído de fuera (chapines, jervillas, zapatos borceguíes botas y } \\
\text { zapatos borceguíes pantuflos), chiquerería, adargas, látigos, aciones, etc., } \\
\text { salida de corambre curtida y la corambre en pelo pertenecen a la aduana }\end{array}$} \\
\hline Corambre de la carnicería & Exenta \\
\hline
\end{tabular}




\begin{tabular}{|c|c|}
\hline $\begin{array}{l}\text { Cuero comprado a labradores y criadores, y la corambre de Cádiz pagan } \\
\text { alcabala }\end{array}$ & \\
\hline \multirow{3}{*}{$\begin{array}{l}\text { Importado por mar para curtir: } \\
\text { Cuero de buey o vaca } \\
\text { Pellejo de cabra, carnero u oveja }\end{array}$} & \\
\hline & $13 \mathrm{mrs}$. \\
\hline & 2 mrs. \\
\hline \\
\hline \multirow{3}{*}{$\begin{array}{l}\text { Cuero de buey o vacuno } \\
\text { Cuero de cordero } \\
\text { Docena de pellejos de carneros o cabras }\end{array}$} & 20 mrs. \\
\hline & $1 \mathrm{mr}$. \\
\hline & $5 \mathrm{mrs}$. \\
\hline Arroba de yerba para curtir, zumaque y arrayán & $4 \mathrm{mrs}$. \\
\hline Importadas por el propio artesano & 2 mrs. \\
\hline Arroba de barrón & 3 blancas \\
\hline \multicolumn{2}{|l|}{ Cuero de buey o vacuno echado en pelambre: } \\
\hline \multirow[t]{2}{*}{ Arrendatario saliente } & $6 \mathrm{mrs}$. \\
\hline & $14 \mathrm{mrs}$. \\
\hline \multirow{3}{*}{$\begin{array}{l}\text { Cuero importado por mar de buey o vacuno, de } 30 \text { mrs. por pieza, en } \\
\text { pelambre: } \\
\text { Arrendatario saliente }\end{array}$} & \\
\hline & 4 mrs. \\
\hline & $9 \mathrm{mrs}$. \\
\hline \multicolumn{2}{|l|}{ Cuero importado por mar de buey o vacuno, de $30 \mathrm{mrs}$. por pieza, alisado: } \\
\hline \multirow[t]{2}{*}{ Arrendatario saliente } & $8 \mathrm{mrs}$. \\
\hline & $5 \mathrm{mrs}$. \\
\hline \multicolumn{2}{|l|}{$\begin{array}{l}\text { Cuero importado por mar de buey o vacuno, de } 30 \mathrm{mrs} \text {. por pieza, en el } \\
\text { noque: }\end{array}$} \\
\hline \multirow{2}{*}{$\begin{array}{l}\text { Arrendatario saliente } \\
\text { Arrendatario entrante }\end{array}$} & $7,5 \mathrm{mrs}$ \\
\hline & $5,5 \mathrm{mrs}$. \\
\hline \multicolumn{2}{|l|}{$\begin{array}{l}\text { Cuero importado por mar de buey o vacuno, de } 30 \text { mrs. por pieza, en } \\
\text { zumaque, la mitad para cada uno }\end{array}$} \\
\hline \multicolumn{2}{|l|}{ ALCABALA DE LA ROPA HECHA } \\
\hline Venta de ropa hecha & $10 \%$ \\
\hline \multicolumn{2}{|c|}{ ALCABALA DE LAS CARRETADAS Y ESQUILMOS DE UVAS QUE SE VENDEN } \\
\hline \multicolumn{2}{|c|}{ ALCABALA DE LAS CARNES QUE SE VENDEN Y PESAN EN EL RASTRO } \\
\hline
\end{tabular}


Como se aprecia claramente, en el almojarifazgo de Sanlúcar hubo dos clases de derechos. Uno, el cobrado sobre el tráfico comercial de mercancías, exigido por las procedentes o con destino fuera del partido fiscal del arzobispado de Sevilla y obispado de Cádiz, así como del propio reino de Castilla, llegadas o sacadas por mar, que en la aduana local abonaban almojarifazgo y alcabala de la primera venta, cuyas tarifas desconocemos. Este gravamen fue el único de este tipo que a partir del reinado de los Reyes Católicos estuvo en poder de un señor territorial, pues los restantes artículos importados o exportados por los puertos de la Andalucía atlántica o del Mediterráneo debieron tributar al almojarifazgo mayor de Sevilla, perteneciente a la Hacienda real, en el que a partir de 1498 se centralizaron todos los almojarifazgos $\operatorname{costeros}^{25}$. De otro lado, como en otros lugares, se abonaron una serie de alcabalas y rentas por distintos conceptos, algunas específicas sobre determinados productos como el ganado, pescado o la carne; otras, como las alcabalas viejas más arriba vistas, también por la entrada y salida de artículos, no necesariamente por mar, o por su reventa, tras tributar en la aduana almojarifazgo; las hubo por la puesta a la venta del género, o por el uso de pesos y medidas, como las cobradas por el almotacén; así como tasas sobre determinadas actividades artesanales.

\subsection{Otros almojarifazgos}

Algo parecido ocurrió en Palos de la Frontera, en parte también perteneciente a esta Casa ducal de Medina Sidonia. Al menos desde 1395 su aduana y almojarifazgo, al que tributaban todas las mercancías que circulaban por el lugar, estuvieron en poder de su señor. Por las ordenanzas de la década de 1480 podemos saber qué rentas se cobraban en el señorío, mientras que otras de 1519-21 recogen en parte estas del siglo XV, aunque modifican y aclaran algunos aspectos. Las primeras fijan el arancel del impuesto sobre el comercio exterior, como en otros lugares, en el $10 \%$ sobre las importaciones y el 2,5 para las exportaciones. Los textiles de lana, lienzos y otros de seda se incluían dentro de la renta de los paños, que a veces podía ser arrendada con el propio almojarifazgo, pero tenía una tarifa propia ad valoren del $5 \%$ sobre la entrada y del 2,5 por la salida, o $12 \mathrm{mrs}$. por pieza y 5 dineros por vara para los exportados; así, en 1503 el almojarifazgo y la renta de los paños ascendieron a $44.000 \mathrm{mrs}$. Por su parte, la saca por mar del aceite estaba gravada con el diezmo, aunque por tierra pagaba lo mismo que el resto de mercancías, el 2,5\%; el de los vecinos era franco, según las costumbres del siglo XVI, aunque si lo habían traído de fuera al meterlo debían dar el 5\%, y el 2,5 al volver a sacarlo. Si seguimos con dichas costumbres, el trigo introducido estaba gravado con 2 mrs. por fanega, mientras que la cebada daba 1 .

Se dice en las citadas ordenanzas que algunos de los derechos de la pesca, caso de la renta de la cuarentena $(2,5 \%)$, pertenecían a la renta mayor del almojarifazgo. Los otros también pudieron haber estado incluidos en él, si bien no se habrían

25. J.D. González Arce. "Arrendamiento de rentas y negocio fiscal en el señorío de Villena a finales de la Edad Media" (en prensa). 
exigido en concepto de importación y exportación, como la anterior. Si se sacaba género por tierra, en bestias, carretas u otra forma, se darían $12 \mathrm{mrs}$. por carga mayor y 8 por la menor; si se hacía por mar, se pagaba la antedicha cuarentena, siempre en dinero y no en especie; aunque si se trataba de cazones o sardinas solo se abonarían 6 mrs. por carga mayor o 3 por la menor, tanto por vía terrestre como marítima; del marisco, 3 mrs. ó 3 blancas, respectivamente. Esta tasa de exportación cobrada por los arrendatarios del almojarifazgo debían satisfacerla tanto los foráneos como los vecinos, pero éstos estaban exentos de lo que fuese de su labranza (¿pescado salado o ahumado?). Ante ellos había que manifestar todo el que llegase en pesqueros a la costa, antes de ser descargado; misma obligación que tenían los mercaderes cuando querían llevárselo en otras embarcaciones, para que les fuese cobrada la exacción. Según las ordenanzas del siglo XVI, esta salida de pesca estaba gravada además con una alcabala del 5\%. Por lo que respecta a la renta del pescado (que en 1503 sumó 46.000 mrs.), en ella contribuía con la veintena $(5 \%)$ el fresco comprado en la ribera de la villa por forasteros. La renta de la playa (de 18.000 mrs., en 1503) se exigía por las capturas realizadas entre el Puntal de la Puerca y el Río del Oro (en Almonte), dentro del alfoz de la villa, y su canon era del $10 \%$, a abonar a los arrendatarios en las mismas playas. Mientras que la renta de la alota y los bodegones (6.600 mrs., en 1503), también del 10\%, comprendía el género procedente de alta mar y el de bajura del término, desde el estero de Domingo Rubio hasta el Puntal de la Puerca, luego vendido en dicho almacén o bodegones, salvo el de los barcos de los vecinos que se incluía en la cuarentena. Antes de manifestar las mercancías a los almojarifes, éstas quedaban depositadas la citada alota, sita en la ribera de la villa, donde también se cerraban los tratos sobre las pesquerías. Las naves foráneas allí fondeadas pagaban derechos de anclaje: 1 dobla de oro las gruesas de alta borda y $12 \mathrm{mrs}$. los barcos con cópano.

En cuanto a lo que podemos considerar como almojarifazgo menor, las ordenanzas del siglo XV mencionan unos derechos fijos a dar por el vendedor y el comprador de $1 \mathrm{mr}$. por bestia menor y 2 por la mayor; aunque las del XVI dicen que era costumbre de la localidad no entregar nada por los caballos y mulas de silla, mientras que por el resto de cuadrúpedos el comprador abonaría el 5\% y el vendedor 4 mrs. por cabeza. Si volvemos a la normativa del XV, tanto por tales animales como por el resto del ganado el comprador satisfaría de alcabala vieja el $5 \%$. Había otra exacción sobre la venta de la carne, o renta de las libras, también del 5\%, según se desprende de las condiciones de arrendamiento de las carnicerías de 1489-90, que en 1503 rentaron $41.000 \mathrm{mrs}$. El uso de las medidas para la comercialización de trigo, cebada o harina conllevaba el abono de un cozuelo por fanega, como los vistos más arriba, lo que supuso, en 1503, $60.000 \mathrm{mrs}^{26}$

26. M.A. Ladero Quesada. Los señores, pp. 163-164, 176, 183-187, 207-211. Véase también A. González Gómez. "Ordenanzas...”, pp. 253-257, 270-277, sobre las ordenanzas del siglo XVI y las rentas de Palos, a partir de la Hacienda regia (AGS, Expedientes de Hacienda, 2, f. 259), porque hacia finales del siglo XV la mitad de la localidad pertenecía a los Reyes Católicos; aunque este último autor hace interpretaciones erróneas, caso, por ejemplo, de la "bota" (alota) y bodegones, que refiere como del vino, o lo que llama del "Pozuelo", que identifica con una dehesa, en lugar del cozuelo. 
Sin llegar a la importancia que alcanzó el almojarifazgo aduanero de Sanlúcar de Barrameda, la Casa de Medina Sidonia también poseyó otros en diferentes señoríos, caso de Conil, Villarrasa, la propia Medina Sidonia, La Torre de Guzmán (Conil de la Frontera), Vejer, Chiclana (donde se arrendaba junto con las rentas del aceite, jabón y noveno) y Jimena (unido al terzuelo), cuya composición descono$\operatorname{cemos}^{27}$. Como en Jerez y Arcos, en Medina Sidonia y Alcalá de los Gazules se demandaron alcabalas sobre el consumo comprendidas en el almojarifazgo señorial, al margen de las alcabalas reales, o, al menos, derechos aduaneros. En 1409 los tutores de Juan II se dirigieron al alcalde mayor jerezano, al que ordenaron arrendar las rentas de estas dos últimas villas: el almojarifazgo, portazgos y otras, anteriormente pertenecientes al duque de Cabra pero en ese momento retornadas al realengo. Las condiciones serían las mismas que en 1407, cuando dichas imposiciones se encontraban bajo la titularidad ducal. Además, los artículos sujetos al pago de diezmo, veintena o cuarentena pertenecientes al almojarifazgo debían abonar la tasa en la moneda nueva que se acababa de acuñar, si bien el resto de las gabelas del almojarifazgo, portazgo y otras se podían pagar en piezas viejas ${ }^{28}$.

En 1477, el I marqués de Cádiz y III conde de Arcos, Juan Ponce de León, fundó el lugar de Chipiona, donde con probabilidad existió previamente una aldea perteneciente al término de Rota. Con el fin de atraer a nuevos habitantes, el señor concedió una carta puebla. En ella se les eximía durante los primeros 15 años de todo tipo de tributos reales y concejiles (pedidos, monedas, servicios...), e incluso los liberó del pago de almojarifazgo y alcabalas, tanto en la propia Chipiona como en Rota; si bien debían comunicar sus tratos con forasteros al recaudador/ arrendatario señorial de estos derechos. Tales forasteros sí correrían con estas tributaciones, aunque obtuvieron sustanciales rebajas en comparación a lo que se demandaba en Sevilla. Durante los 5 años iniciales de la fundación solo satisfarían de almojarifazgo el 2,5\%, y el 5 en concepto de alcabala; mientras que en adelante ambos quedaron en el 5-10\%, respectivamente. Trascurridos los 15 años de gracia, los nuevos pobladores pagarían los mismos derechos que los roteños, incluidos almojarifazgo y alcabala ${ }^{29}$.

En 1494, la casa rival de los Ponce de León, la de Medina Sidonia, se inspiró en esta carta puebla de Chipiona para conceder otra similar a Trebujena, con la que segregarla de Sanlúcar de Barrameda. Sin embargo, fueron más restrictivos. La franqueza inicial se redujo a solo 10 años; si bien más adelante, en una adición, fueron ampliados a 15. Además, la exención solo incluía alcabala, para los productos locales, a pesar de que la nueva puebla contaba con un puerto propio, en el Guadalquivir, en el donadío de Alventos, en el que se podía haber dejado de demandar, o al menos rebajado, el almojarifazgo del que con pleno derecho sí

27. E. Solano Ruiz. "La hacienda...", pp. 102-103.

28. AMJF, AC 1410, f. 24r-v. En un cuaderno de las rentas de la hacienda regia del siglo XV, sin fecha, en el partido de Jerez de la Frontera se comprenden los derechos de Medina Sidonia, Alcalá de los Gazules y el almojarifazgo de Tarifa (AGS, CC, Diversos, 1, 93).

29. A. Franco Silva. Estudios sobre ordenanzas municipales (siglos XIV-XVI). Cádiz, 1998, pp. 247-287. 
gozaban los Pérez de Guzmán. Antes bien al contrario, en 1496 el concejo de Jerez de la Frontera protestó ante el duque porque allí se exigían nuevos tributos nunca cobrados sobre las mercancías que por él entraban o salían hacia, o desde, dicha ciudad. No obstante, no hemos de olvidar que las citadas alcabalas eran las alcabalas viejas que se comprendieron en el almojarifazgo local, más arriba vistas ${ }^{30}$.

\section{CONCLUSIÓN}

En resumen, en buena aparte de las poblaciones conquistadas al Islam en esta baja Andalucía, al menos en los principales núcleos de las antiguas taifas, se formó un almojarifazgo local que comprendía entre las rentas inicialmente pertenecientes al nuevo monarca cristiano, aparte de los impuestos habidos en el resto de Castilla, también algunas otras de época musulmana, exigidas en tiempos de los reinos musulmanes. Muchas de ellas, en los que luego serían lugares de señorío, en su mayor parte pasaron a engrosar las haciendas nobiliarias, a veces también las municipales.

Algo que, sin embargo, no ocurrió en El Puerto de Santa María, puesto que el concejo de esta villa fue fundado por Alfonso X con posterioridad a la conquista del territorio, de ahí que no contase con un almojarifazgo propio; de manera que no aparecen esta clase de exacciones entre los derechos percibidos por la Casa de Medinaceli, que sólo disfrutó del almojarifazgo aduanero cuando pudo recaudarlo en lugar de la Corona o cuando ésta le cedió alguna participación sobre el mismo. No obstante, ciertos derechos cobrados por dicha Casa recuerdan a las "alcabalas viejas" más arriba vistas, sin duda por influencia de los señoríos próximos ${ }^{31}$.

En este sentido, como hemos podido comprobar, los diferentes almojarifazgos locales reunieron una serie de rentas similares entre sí, bien por tener un origen común, a partir de la herencia musulmana o del ordenamiento jurídico y el derecho local recibido tras la conquista, o bien por su proximidad geográfica, lo que habría dado lugar al intercambio de experiencias en los tipos y gestión de la punción fiscal. Entre ellas, son de destacar, en primer lugar, las tarifas sobre la importación y exportación de mercancías fuera del término concejil, que solían estar gravadas con aranceles del 2,5, 5 y $10 \%$, por lo que fueron denominadas en un principio como cuarentenas, veintenas o diezmos, pero que luego adquirieron el nombre genérico de almojarifazgo, por tratarse del derecho más valioso incluido este régimen de tesorería conjunto. Cuando estos cánones sobre el tráfico comercial se cargaron sobre artículos procedentes de otros lugares cercanos y no sobre los llegados por mar o desde tierras exteriores a la Corona de Castilla, adoptaron

30. M. González Jiménez. "La Carta-Puebla de Trebujena (1494)”. HID, 11, 1984, pp. 381-382. AMJF, AC 1496, ff. 227v-228r.

31. J.J. Iglesias Rodríguez. "Ciudad y fiscalidad señorial: Las rentas del Puerto de Santa María en el siglo XVI", Las ciudades andaluzas (siglos XIII-XV). Actas del VI Coloquio Internacional de Historia Medieval de Andalucía, Málaga, 1991; J.J. Iglesias Rodríguez. Monarquía y nobleza señorial en Andalucía: estudios sobre el señorio de El Puerto (siglos XIII-XVIII). Sevilla 2003, pp. 87-115. 
más bien la forma de alcabalas, llamadas viejas para diferenciarlas de la alcabala real, aparecida a mediados del siglo XIV. Las antedichas, con tipos impositivos de en torno al $5 \%$, fueron exigidas asimismo en algunas operaciones de compraventa que no conllevaron el cambio de jurisdicción municipal, sobre ciertas actividades productivas artesanales o por el uso de pesos y medidas. Aunque estos últimos, en ocasiones, contaron con tasas específicas por su utilización, cuando eran monopolio concejil o del almojarifazgo de cada localidad. También algunos artículos, sobre todo los de más valor o de demanda más frecuente, estuvieron sujetos a contribuciones propias, caso de las numerosas habidas para los paños el pescado y el vino. Situación similar a la vivida con el diezmo, antiguo zakat islámico, cobrado sobre ciertos artículos agrícolas, como el aceite, u objetos elaborados con tierra, como tejas y ladrillos.

\section{BiBLIOGRAFÍA}

Carriazo Rubio, Juan Luis. "Notas sobre fiscalidad señorial: el almojarifazgo de Arcos de la Frontera a comienzos del siglo XV", en IV Coloquio de la Red Arca Comunis, Agentes de los sistemas fiscales en Andalucía y los reinos hispánicos (siglos XIII-XVII). Málaga, mayo de 2013.

Franco Silva, Alfonso. Estudios sobre ordenanzas municipales (siglos XIV-XVI). Cádiz, 1998.

Galán Sánchez, Ángel. "Hacienda y fisscalidad en el reino de Granada: algunas razones para su estudio". Crónica Nova, 31 (2005), pp. 11-22.

Galán Parra, Isabel. "Las ordenanzas de 1504 para Huelva y el Condado de Niebla”, Huelva en su Historia, 3 (1990), pp. 107-174.

García Fernández, Manuel. El reino de Sevilla en tiempos de Alfonso XI (13121350). Sevilla, 1989.

—. "Morón de la Frontera y Enrique II: los privilegios reales de 1378", Archivo hispalense, 74, 227 (1991), pp. 3-25.

—. "La villa de Osuna entre Pedro I y Enrique II: algunas reflexiones sobre la guerra civil castellana en Andalucía (1366-1371)", Historia. Instituciones. Documentos, 31 (2004), pp. 211-225.

González Arce, José Damián. "El almojarifazgo de Sevilla, una renta feudal”. Actas del VI Coloquio Internacional de Historia Medieval de Andalucía. Las ciudades Andaluzas (siglos XIII-XVI). Málaga, 1991, pp. 1512-160.

—. "La política fiscal de Alfonso X en el reino de Murcia: portazgo y diezmos". Studia Historica, Historia Medieval, 10 (1992).

—. "Almojarifazgo y economía urbana en el reino de Murcia, siglo XIII". Hispania, 53 (1993), pp. 5-34.

—. "Documentos sobre el almojarifazgo de Sevilla". Historia. Instituciones. Documentos. 20 (1993), pp. 165-196.

—. "Las rentas del almojarifazgo de Sevilla". Studia Historica, Historia Medieval, 15 (1997), pp. 209-254. 
-. La fiscalidad del señorío de Villena en la baja Edad Media. Albacete, 2002.

—. "Las rentas del almojarifazgo de Toledo". Anales Toledanos, 61 (2005), pp. 39-70.

—. "Del diezmo islámico al diezmo real. La renta agraria en Toledo (ss. XI-XV)", Historia Agraria, 45 (2008), pp. 17-39.

- . "De conjunto de rentas a impuesto aduanero. La transformación del almojarifazgo durante el siglo XIV en el reino de Murcia". Anuario de Estudios Medievales, 42/2 (2012), pp. 669-696.

-. "Los beneficiarios de la fiscalidad medieval. El caso del diezmo del aceite del almojarifazgo de Sevilla en el siglo XV". Medievalismo, 22 (2012), pp. 99-137.

- " "Actividad económica y exacciones fiscales. El almojarifazgo de Jerez en los siglos XIII-XV", Congreso Cientifico Jerez 1264-2014: 750 años, Jerez de la Frontera, 3-7 de febrero de 2014.

- . "Aproximación a la producción oleica del Aljarafe durante el siglo XV a partir de fuentes fiscales. El diezmo del aceite del almojarifazgo de Sevilla", Historia Agraria (en prensa).

- . "Arrendamiento de rentas y negocio fiscal en el señorío de Villena a finales de la Edad Media" (en prensa).

González Gómez, Antonio. "Ordenanzas municipales de Palos de la Frontera (1484-1521)", Historia. Instituciones. Documentos, 3 (1976), pp. 247-280.

González Jiménez, Manuel. "La Carta-Puebla de Trebujena (1494)", Historia. Instituciones. Documentos, 11 (1984), pp. 375-385.

-. "Privilegios de los maestres de Alcántara a Morón de la Frontera", Archivo hispalense, 70, 214 (1987), pp. 3-46.

- (Ed.). Diplomatario andaluz de Alfonso X. Sevilla, 1991.

- y García Fernández, Manuel. Actas capitulares de Morón de la Frontera (14021426). Sevilla, 1992.

González Mínguez, César. El portazgo en la Edad Media. Aproximación a su estudio en la Corona de Castilla. Bilbao, 1989.

Iglesias Rodríguez, Juan José. "Ciudad y fiscalidad señorial: Las rentas del Puerto de Santa María en el siglo XVI", Las ciudades andaluzas (siglos XIII-XV). Actas del VI Coloquio Internacional de Historia Medieval de Andalucía, Málaga, 1991, pp. 215-224.

-. Monarquía y nobleza señorial en Andalucía: estudios sobre el señorio de El Puerto (siglos XIII-XVIII). Sevilla, 2003.

Ladero Quesada, Miguel Ángel. "Almojarifazgo sevillano y comercio exterior de Andalucía en el siglo XV”. Anuario de Historia Económica y Social, 2 (1969), pp. 69-116.

—. La hacienda real de Castilla en el siglo XV. La Laguna, 1973.

- . "Los primeros pasos de la alcabala castellana, de Alfonso X a Pedro I". Anuario de Estudios Medievales, 22 (1992), pp. 785-901.

-. Niebla, de reino a condado. Noticias sobre el Algarbe andaluz en la baja Edad Media. Madrid, 1992.

—. Fiscalidad y poder real en Castilla (1252-1369). Madrid, 1993. 
-. Los señores de Andalucía. Investigaciones sobre nobles y señoríos en los siglos XIII a XV. Cádiz, 1998.

—. La Hacienda Real de Castilla, 1369-1504. Madrid, 2009.

-. "Sanlúcar de Barrameda, antepuerto de Sevilla, a finales del siglo XV", Mundos medievales: espacios, sociedades y poder: homenaje al profesor José Ángel García de Cortázar y Ruiz de Aguirre. Santander, 2012.

- y González Jiménez, Manuel. "La población de la frontera de Gibraltar y el repartimiento de Vejer (siglos XIII y XIV)", Historia. Instituciones. Documentos, 4 (1977), pp. 199-316.

Moreno Ollero, Antonio. Sanlúcar de Barrameda a fines de la Edad Media. Cádiz, 1983.

Navarro Sáinz, José María. "Aspectos económicos de los señoríos de los duques de Medina Sidonia a principios del siglo XVI", Huelva en su Historia, 2 (1988), pp. 319-345.

Peinado Santaella, Rafael. "Fiscalidad señorial y tráfico comercial en Andalucía a finales de la Edad Media: Notas para su estudio". Hacienda y comercio. Actas del II coloquio de historia medieval andaluza. Sevilla, 1982, pp. 133-158.

Porras Arboledas, Pedro Andrés. "Las tasas sobre la circulación y venta de mercancías en León y Castilla durante la Edad Media". En la España Medieval, 5 (1986), pp. 849-860.

-. "Los portazgos en León y Castilla durante la Edad Media. Política real y circuitos comerciales". En la España Medieval, 15 (1992), pp. 163-211.

Quintanilla Raso, María Concepción. "La reglamentación de una villa de señorío en el tránsito de la Edad Media a la Moderna. Ordenanzas de Cartaya (Huelva)", Historia. Instituciones. Documentos, 13 (1986), pp. 189-259.

Solano Ruiz, Emma. "La hacienda de las casas de Medina Sidonia y Arcos en la Andalucía del siglo XV", Archivo Hispalense, 55, 168 (1972), pp. 85-176.

Fecha de recepción del artículo: febrero 2014

Fecha de aceptación y versión final: julio de 2014 
